\title{
A Lateglacial palaeosol cover in the Altdarss area, southern Baltic Sea coast (northeast Germany): investigations on pedology, geochronology and botany
}

\author{
K. Kaiser ${ }^{1,{ }^{*}}$, A. Barthelmes ${ }^{2}$, S. Czakó Pap ${ }^{3}$, A. Hilgers ${ }^{4}$, W. Janke ${ }^{3}$, P. Kühn ${ }^{5}$ \& M. Theuerkauf ${ }^{2}$
}

1 University of Marburg, Dept. of Geography, Deutschhausstrasse 10, D-35032 Marburg, Germany.

2 University of Greifswald, Dept. of Botany, Grimmer Strasse 88, D-17487 Greifswald, Germany.

3 University of Greifswald, Dept. of Geography, Jahnstrasse 16, D-17487 Greifswald, Germany.

4 University of Köln, Dept. of Geography, Albertus-Magnus-Platz, D-50923 Köln, Germany.

5 University of Tübingen, Dept. of Physical Geography, Rümelinstrasse 19-21, D-72070 Tübingen, Germany.

* Corresponding author. Email: knut.kaiser@gmx.net

Manuscript received: April 2005; accepted: July 2006

In memory of Wolfram Lemke (1955 - 2005)

\begin{abstract}
A new site with Lateglacial palaeosols covered by $0.8-2.4 \mathrm{~m}$ thick aeolian sands is presented. The buried soils were subjected to multidisciplinary analyses (pedology, micromorphology, geochronology, dendrology, palynology, macrofossils). The buried soil cover comprises a catena from relatively dry ('Nano'-Podzol, Arenosol) via moist (Histic Gleysol, Gleysol) to wet conditions (Histosol). Dry soils are similar to the so-called Usselo soil, as described from sites in NW Europe and central Poland. The buried soil surface covers ca. $3.4 \mathrm{~km}^{2}$. Pollen analyses date this surface into the late Allerød. Due to a possible contamination by younger carbon, radiocarbon dates are too young. OSL dates indicate that the covering by aeolian sands most probably occurred during the Younger Dryas. Botanical analyses enables the reconstruction of a vegetation pattern typical for the late Allerød. Large wooden remains of pine and birch were recorded.
\end{abstract}

Keywords: buried palaeosol, Late Quaternary, palaeoenvironment, Usselo soil

\section{Introduction}

The so-called 'European sand belt' spreads over ca. 2,500 km from NW to NE Europe and comprises large parts of the old and young morainic areas of Germany (Zeeberg, 1998; Fig. 1). Beside former ice-marginal streamways, outwash-plains and ice-dammed lakes, also large areas covered by dunes and coversands are an important feature of this zone. Stratigraphically, the aeolian deposits belong mainly to the Weichselian Lateglacial and the Holocene. The analysis of buried soils / palaeosols in this area is known as a reliable method for dividing aeolian deposits and deriving stages of landscape evolution (pedostratigraphy). Generally, buried soils in this area can be divided into soils strongly influenced by groundwater such as Gleysols and Histosols (peat layers), and soils of more or less dry terrestrial sites such as Arenosols, ('Nano'-) Podzols, and Cambisols.

In the Netherlands, western Germany, and western Denmark the so-called Usselo soil (Dücker \& Maarleveld, 1957; Hijszeler, 1957) is a characteristic and widespread buried soil of the Weichselian Lateglacial. It is classified as a weakly podzolized Arenosol (ISSS-ISRIC-FA0, 1998) or as a weakly podzolized Regosol (AG Boden, 1994). Radiocarbon dates, pollen analyses, and archaeological evidence characterises the Usselo soil as a mainly Allerød soil formation (e.g. Kolstrup \& Jørgensen, 1982; Stapert \& Veenstra, 1988; Hoek, 1997; Kasse, 1999; Vandenberghe et al., 2004; Kaiser \& Clausen, 2005). A similar buried soil of identical age has been found in central and northwestern Poland (Manikowska, 1991; Jankowski, 2002). 


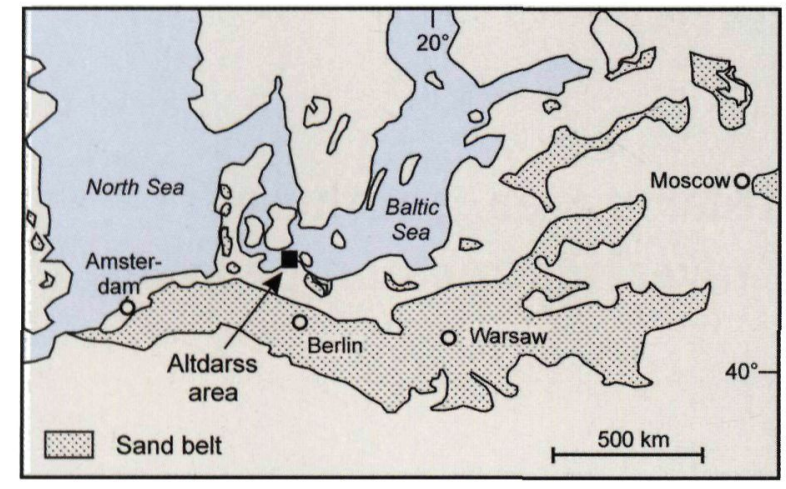

a.

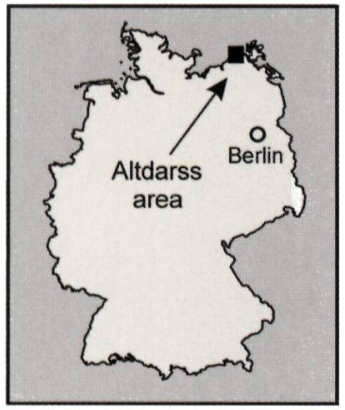

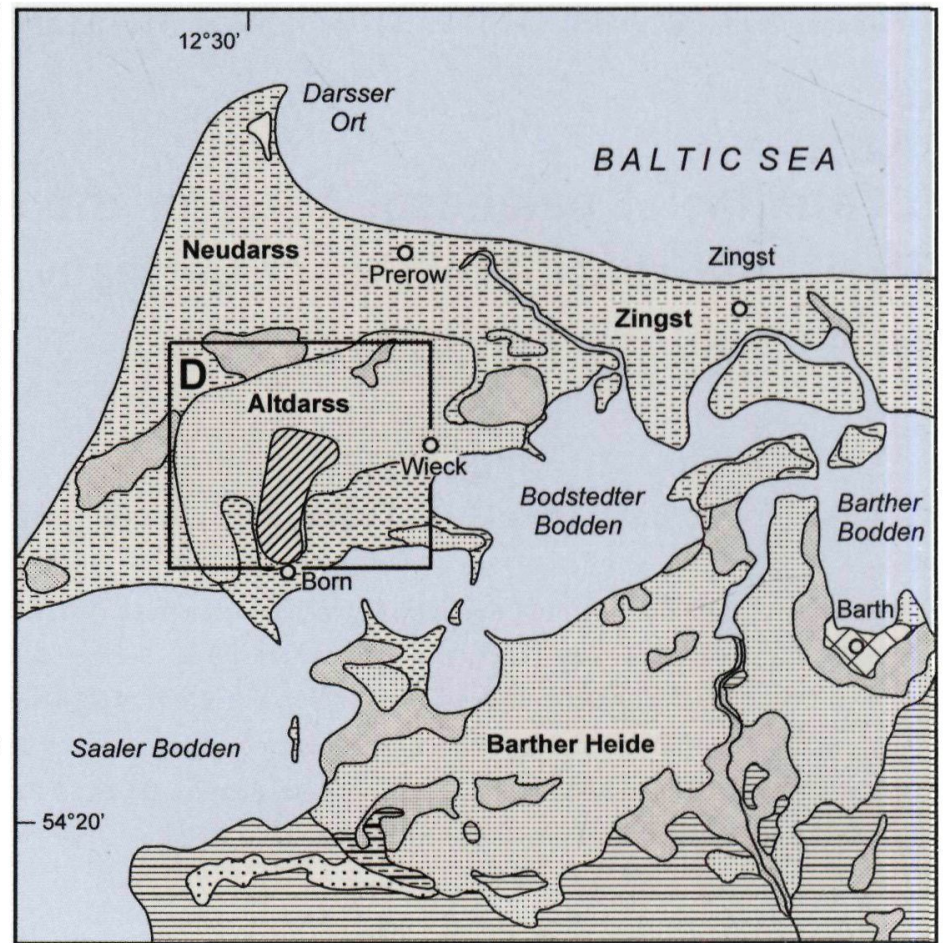

c.

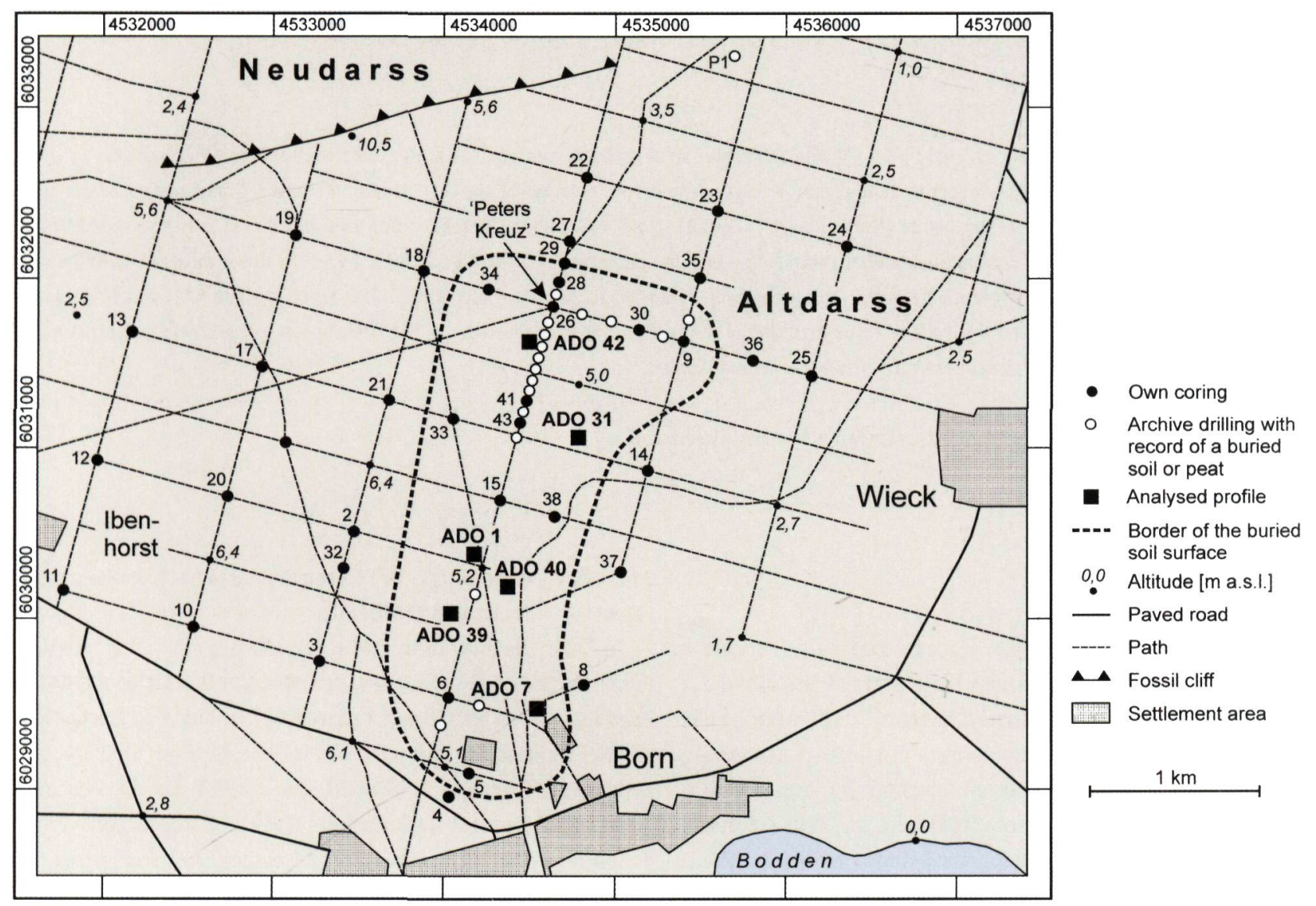

d.

Fig. 1. Location, geology, and topography of the study area; a. European sand belt (after Zeeberg 1998, modified); b. Location in Germany; c. Geology of the Altdarss area and surroundings (after Geologischer Dienst Schwerin 1957, modified); d. Topography, corings, and profiles analysed of the study area (topography after Topographical Map $1: 25$ 000). 
From central Europe the stratigraphically identical but pedologically different Finow soil was described. It is found in and around northeastern Germany's Federal State of Brandenburg. The Finow soil has features of a weakly developed Cambisol (Bussemer et al, 1998; Schlaak, 1998; Schirmer, 1999). Radiocarbon and luminescence dates as well as archaeological evidence support the assumption, that a stable soil surface still existed during the early part of the Younger Dryas (Hilgers et al., 2001; Bogen et al., 2003; Hilgers, 2006). Furthermore, possible single occurrences of Lateglacial Cambisols were reported from Belgium (Kasse, 1999) and Poland (Borowka et al., 1999; Jankowski, 2002). However, there is no sufficient explanation (climate?, geological / edaphic conditions?) for the apparent 'provinces' of the Usselo and Finow soil.

Little attention has been given so far to the lithostratigraphy and pedostratigraphy of aeolian deposits along the northern border of the European sand-belt comprising the coastal areas and the hinterland of the southern Baltic Sea. First dated records of Lateglacial buried terrestrial soils became available not before the 1980s. These studies revealed i) the existence of the Usselo and the Finow soil in the estuary region of the Oder River and ii) a widespread aeolian sedimentation during the Younger Dryas (Borowka et al., 1986, 1999; Bogen et al., 2003). However, the lateral characteristics of the Lateglacial soil cover remained vague and chronological control was inadequate including the wide lack of accompanying palaeoecological data. Up to now, only a few studies in the European sand belt tried to differentiate the palaeosol cover spatially and, furthermore, tried to explain the site development based on a multidisciplinary approach (van Geel et al., 1989; Kowalkowski et al., 1999; Friedrich et al., 2001).

The buried soil cover in the Altdarss area was discovered during geomorphological fieldwork in 1999 (Kaiser, 2001). Similar to the occurrences in the Oder River area, it is situated in a Late Pleniglacial glaciolacustrine basin, which also passed through Lateglacial terrestrial and aeolian stages (Fig. 1). Extraordinary circumstances such as the large extension of an undisturbed buried land surface (ca. $3.4 \mathrm{~km}^{2}$ ), the number of buried soil types, and the preservation of plant remains including wood made a detailed investigation of the site worthwhile. First of all, the investigations focussed on a comprehensive description of the palaeosols. Special attention was given on the manifold dating of the stratigraphy including optically stimulated luminescence dating (OSL). A final synthesis aimed at a palaeoenvironmental synthesis resulting primarily in a transect of Lateglacial soils and vegetation.

Unfortunately, the investigation presented here is possibly the 'final' documentation of the research object. In the near future, a fallen groundwater level caused by permanent drinking water conveyance since the 1960s will result in a far reaching destruction of the organic components in the buried soils.

\section{Settings}

In the Late Pleniglacial, the Altdarss area was part of a large glaciolacustrine basin $\left(>700 \mathrm{~km}^{2}\right)$ comprising also the adjacent areas of the Rostocker Heide and the Barther Heide as well as the later coastal lagoons, the so-called 'Bodden' in German (Fig. 1). To the south, the edge of the basin consisted of unburied dead ice. Flat till plains appeared after melting around 14,000 uncal BP (Görsdorf \& Kaiser, 2001). To the north, the melting of buried dead ice formed extended (sub-) basins, the later water-filled 'Bodden'.

Within the Altdarss area more than 60 deep-reaching drillings, carried out since the 1960s for hydrogeological purposes, are available for stratigraphical conclusions. These drillings indicate the following basin sequence: The base in a depth of ca. $20 \mathrm{~m}$ consists of sandy-loamy till. It is covered by 3 - $4 \mathrm{~m}$ of glaciolacustrine silt. Above follow ca. $15 \mathrm{~m}$ of glaciolacustrine sands, sometimes containing drop stones in the size of gravel. On top occurs a storey of buried soils including peats and gyttjas, which is overlain by $1-3 \mathrm{~m}$ of aeolian sand (Fig. 2). Marine and brackish sediments of the Mid- and Late Holocene rise of the Baltic Sea surround the former 'Altdarss-Island'.

The relief of the Altdarss area is flat to gently undulating with a highest altitude of $10.5 \mathrm{~m}$ a.s.l. Aeolian land forms close to the investigated profiles consist of low longitudinal dunes (1 - $2 \mathrm{~m}$ high, partly several $100 \mathrm{~m}$ long), flat sand sheets, and small deflation hollows.

Soils of the surface are, if relatively dry, classified mainly as well developed (Relic) Gleyic Podzols and Podzols, which have thick covers of raw humus / mor (usually $10-20 \mathrm{~cm}$, but partly up to $50 \mathrm{~cm}$ thick; Billwitz, 1997). Relatively wet soils are classified as anthropogenically drained Histosols and Gleysols. Improved draining started in the early 20th century and was, accompanied by drinking water conveyance, further intensified since the 1960s. This strongly influenced the surface soils and the preservation of the buried soils.

Dry sites are covered by pine forests or used for arable farming. Wet sites are covered by alder forests or used for meadows and pastures. The Holocene vegetation history of the area is well known from palynological investigations performed by Fukarek (1961) and Kaffke \& Kaiser (2002; profile ADP). Prior to the onset of strong human impact on this landscape in the 13th - 14th century, the widespread sandy and podzolized sites were dominated by beech.

\section{Methods}

After an initial survey in 1999 - 2000 with first soil and pollen analyses as well as OSL dating (Kaiser, 2001), the extensive investigation of the Altdarss site took place in 2001-03 comprising grid based coring, digging, and sampling of selected trenches with subsequent pedological, micromorphological, geochronological, and botanical analyses. 


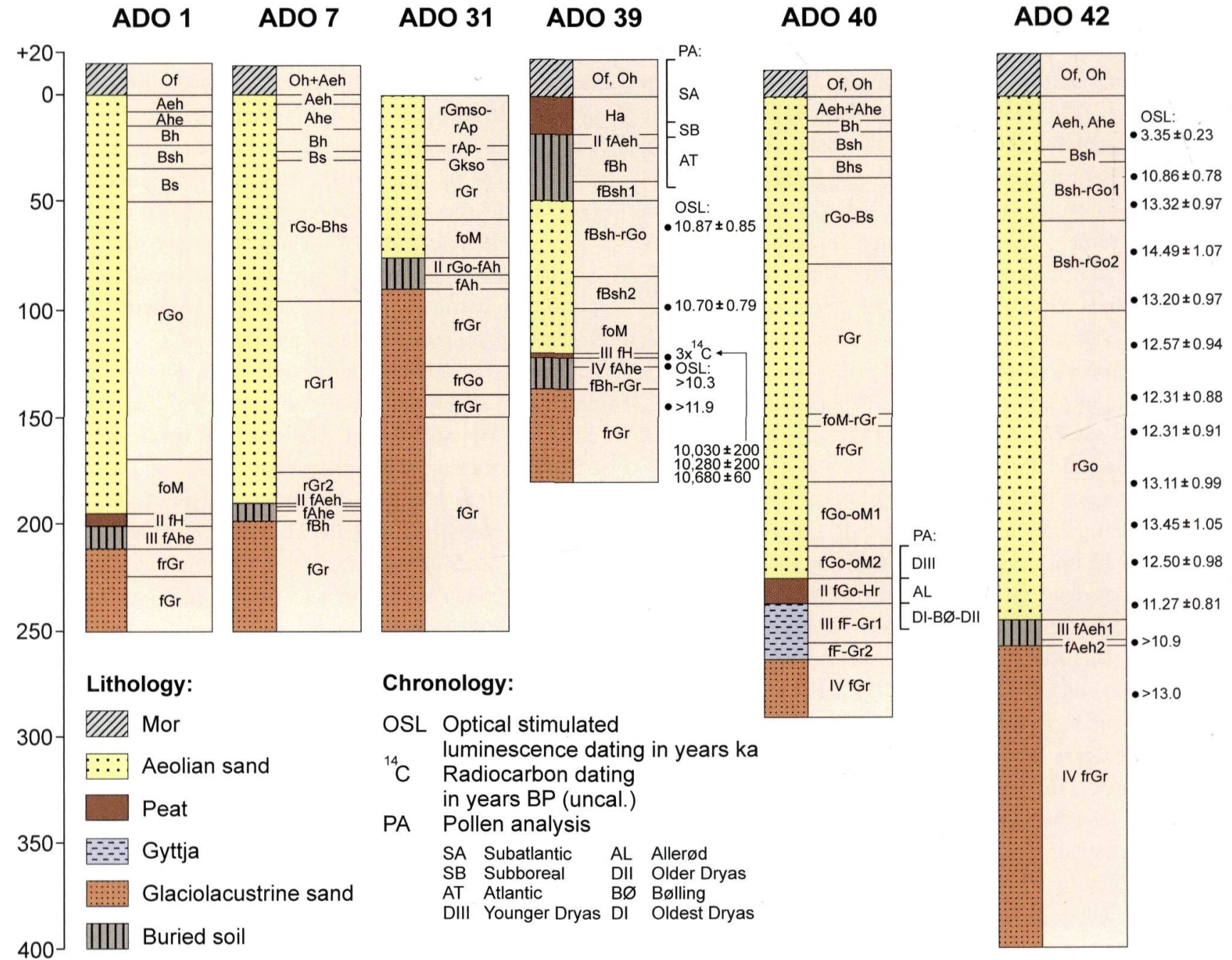

$\mathrm{cm}$

Pedology (meaning of German soil horizons):

\begin{tabular}{lll} 
KA4 & \multicolumn{1}{c}{ Meaning } & WRB \\
H & $\begin{array}{l}\text { Peat horizon } \\
\text { forming of aggregates }\end{array}$ & $\mathbf{H}$ \\
$\mathrm{Ha}$ & strong reduction & $\mathrm{H}$ \\
$\mathrm{Hr}$ & Organic topsoil horizon & $\mathrm{O}$ \\
$\mathrm{O}$ & partly decomposed & $\mathrm{O}$ \\
$\mathrm{Of}$ & most decomposed & $\mathrm{O}$ \\
$\mathrm{Oh}$ & Topsoil and eluvial horizon & $\mathrm{A}$ \\
$\mathrm{A}$ & organic matter accumulation & $\mathrm{Ah}$ \\
$\mathrm{Ah}$ & weak eluviation & $\mathrm{AE}$ \\
$\mathrm{Aeh}$ & medium eluviation & $\mathrm{EA}$ \\
$\mathrm{Ahe}$ & disturbed by ploughing & $\mathrm{Ap}$ \\
$\mathrm{Ap}$ & topsoil matter translocated by wind & $\mathrm{CA}$ \\
oM & Illuvial horizon & $\mathrm{B}$ \\
$\mathrm{B}$ & organic matter concentration & $\mathrm{Bh}$ \\
$\mathrm{Bh}$ & sesquioxid concentration & $\mathrm{Bs}$ \\
$\mathrm{Bs}$ & both organic matter and sesquioxid & $\mathrm{Bsh}, \mathrm{Bhs}$ \\
$\mathrm{Bsh}, \mathrm{Bhs}$ & concentration & \\
& Groundwater horizon & $\mathrm{C}$ \\
$\mathrm{G}$ & predominant oxidation & $\mathrm{Cg}$ \\
$\mathrm{Go}$ & predominant reduction & $\mathrm{Cr}$ \\
$\mathrm{Gr}$ & accumulation of concretions & $\mathrm{Ccs}$ \\
$\mathrm{Gmso} / \mathrm{Gkso}$ & $\mathrm{Cr}$ \\
$\mathrm{F}-\mathrm{Gr}$ & Gr horizon developed from gyttja & \\
& & $\mathrm{suffix} \mathrm{b}$ \\
prefix $\mathrm{f}$ & buried horizon & - \\
prefix r & relic property &
\end{tabular}

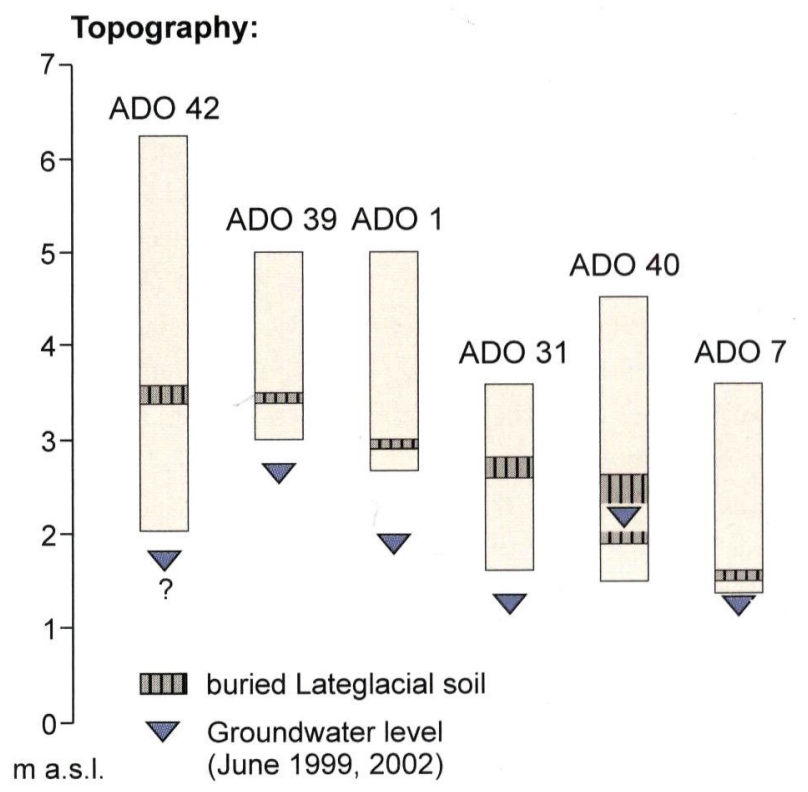

Fig. 2. Profiles investigated of the Altdarss area. 


\section{Pedology}

In a 400 by $800 \mathrm{~m}$ grid, 38 cores were taken using a percussion corer (diameter $5 \mathrm{~cm}$ ). Additionally, several archive drillings were evaluated. Detailed results have been documented in Czakó Pap (2003). Six trenches up to a size of $4 \times 4 \mathrm{~m}$ were excavated in order to provide horizontal sections ('plans') as well as profiles and samples. Different standards were applied to classify soil horizons and soil types (AG Boden, 1994: 'KA4'; ISSS-ISRICFA0, 1998: 'WRB'; Tabs 1, 2). The German KA4-standard (partly modified) was used to name horizons since it is more precisely.
Soil types, however, are classified according to the WRB-standard. Pedological analyses were carried out on 71 samples. After humus destruction and dispersion with sodium pyrophosphate, a pipette and sieving test was used to determine the grain-size distribution. In profile ADO 42 grain-size distribution was determined by laser diffractometry. Samples were treated by burning for two hours $550{ }^{\circ} \mathrm{C}$ to estimate the organic content (loss-on-ignition $=\mathrm{LOI})$. Iron-components $\left(\mathrm{Fe}_{\mathrm{d}}, \mathrm{Fe}_{\mathrm{o}}, \mathrm{Fe}_{\mathrm{p}}\right)$ were extracted following Schlichting et al. (1995). Soil pH was determined potentiometrically in $0.01 \mathrm{M} \mathrm{CaCl}_{2}$. According to AG Boden (1994), depth is measured from the upper limit of the mineralic soil.

Table 1. Pedological parameters of profiles $A D O 1, A D O$ 7, and ADO 31 (analysis: K. Kaiser \& S. Czakó Pap).

Profile AD0 1 (altitude: 5.0 m a.s.l.; German coordinates: RW 4534350, HW 6030450; groundwater level 06/2002: c. 330 cm)

\begin{tabular}{|c|c|c|c|c|c|c|c|c|c|c|c|c|c|}
\hline \multirow{2}{*}{$\begin{array}{l}\text { Depth } \\
(\mathrm{cm})\end{array}$} & \multirow{2}{*}{$\begin{array}{l}\text { Horizon } \\
(\mathrm{KA} 4)\end{array}$} & \multirow{2}{*}{$\begin{array}{l}\text { Horizon } \\
\text { (WRB) }\end{array}$} & \multirow[t]{2}{*}{ Substrate } & \multirow{2}{*}{$\begin{array}{l}\text { Colour } \\
\text { (Munsell) }\end{array}$} & \multicolumn{4}{|c|}{ Grain size distribution (\%) } & \multirow{2}{*}{$\begin{array}{l}\text { LOI } \\
(\%)\end{array}$} & \multirow{2}{*}{$\begin{array}{l}\mathbf{p H} \\
\left(\mathrm{CaCl}_{2}\right)\end{array}$} & \multicolumn{3}{|l|}{ Iron } \\
\hline & & & & & $\begin{array}{l}\text { Clay } \\
(<0.002 \\
\mathrm{mm})\end{array}$ & $\begin{array}{l}\text { Silt } \\
(<0.063 \\
\mathrm{mm})\end{array}$ & $\begin{array}{l}\text { Fine sand } \\
(<0.2 \mathrm{~mm})\end{array}$ & $\begin{array}{l}\text { Med. sand } \\
(<0.63 \mathrm{~mm})\end{array}$ & & & $\begin{array}{l}\mathrm{Fe}_{\mathrm{d}} \\
(\mathrm{mg} / \\
100 \mathrm{~g})\end{array}$ & $\begin{array}{l}\mathrm{Fe}_{\mathrm{o}} \\
(\mathrm{mg} / \\
100 \mathrm{~g})\end{array}$ & $\begin{array}{l}\mathrm{Fe}_{\mathrm{p}} \\
(\mathrm{mg} / \\
100 \mathrm{~g})\end{array}$ \\
\hline+15 & of & 0 & Mor & $2.5 Y R 2.5 / 3$ & - & - & - & - & 85.3 & 3.0 & - & - & - \\
\hline $0-8$ & Aeh & $\mathrm{AE}$ & Aeolian & 10YR2/1 & 0.0 & 10.1 & 84.9 & 5.0 & 12.0 & 3.0 & 0.4 & 19.9 & 35.6 \\
\hline 15 & Ahe & EA & sand & 10 YR5/2 & 0.0 & 5.4 & 90.9 & 3.7 & 2.4 & 3.3 & 0.3 & 4.7 & 5.7 \\
\hline 24 & $\mathrm{Bh}$ & $\mathrm{Bh}$ & & 10YR2/1 & 1.9 & 5.9 & 85.2 & 7.0 & 11.7 & 3.0 & 0.7 & 53.7 & 51.5 \\
\hline 35 & Bsh & Bsh & & $2.5 Y R 2.5 / 3$ & 0.8 & - & 89.6 & 5.7 & 3.5 & 3.8 & 0.9 & 9.2 & 11.7 \\
\hline 50 & Bs & Bs & & $5 Y R 5 / 8$ & 1.3 & 3.6 & 90.3 & 4.8 & 2.9 & 3.8 & 0.9 & 9.6 & 12.2 \\
\hline 170 & rGo & $\mathrm{Cg}$ & & $10 \mathrm{YR} 6 / 8$ & 0.0 & 2.8 & 88.9 & 8.3 & 0.6 & 4.3 & 0.2 & 1.6 & 1.7 \\
\hline 195 & foM & $\mathrm{CAb}$ & & $2.5 Y 6 / 4$ & 0.5 & 3.8 & 90.6 & 5.1 & 1.0 & 4.2 & 0.3 & 5.3 & 7.7 \\
\hline 201 & II $\mathrm{fH}$ & $2 \mathrm{Hb}$ & Peat & $2.5 Y R 2.5 / 3$ & 3.5 & 49.1 & 44.7 & 2.7 & 60.5 & 3.8 & 90.0 & 240.0 & 102.0 \\
\hline 211 & III fAhe & $3 E A b$ & Glacio- & $10 \mathrm{YR} 5 / 3$ & 1.7 & 18.4 & 79.6 & 0.3 & 2.7 & 3.9 & 0.9 & 6.4 & 6.5 \\
\hline 225 & frGr & Crb & lacustrine & $2.5 Y 7 / 3$ & 0.3 & 4.5 & 89.6 & 5.6 & 0.4 & 4.2 & 0.6 & 4.8 & 3.5 \\
\hline $250+$ & $\mathrm{fGr}$ & $\mathrm{Crb}$ & sand & $5 Y 6 / 3$ & - & - & - & - & - & - & - & - & - \\
\hline
\end{tabular}

Surface soil: KA4: Relikt-Gley-Podsol (KA4); WRB: (Relic-) Gleyic Podzol

Buried soil: KA4: schwach podsolierter Moorgley; WRB: weakly podzolized Histic Gleysol

Profile ADO 7 (altitude: $3.6 \mathrm{~m}$ a.s.l.; German coordinates: RW 4534750, HW 6029575, groundwater level 06/2002: c. 250 cm)

\begin{tabular}{|c|c|c|c|c|c|c|c|c|c|c|c|c|c|}
\hline \multirow{2}{*}{$\begin{array}{l}\text { Depth } \\
(\mathrm{cm})\end{array}$} & \multirow{2}{*}{$\begin{array}{l}\text { Horizon } \\
(\mathrm{KA} 4)\end{array}$} & \multirow{2}{*}{$\begin{array}{l}\text { Horizon } \\
\text { (WRB) }\end{array}$} & \multirow[t]{2}{*}{ Substrate } & \multirow{2}{*}{$\begin{array}{l}\text { Colour } \\
\text { (Munsell) }\end{array}$} & \multicolumn{4}{|c|}{ Grain size distribution (\%) } & \multirow{2}{*}{$\begin{array}{l}\text { LOI } \\
(\%)\end{array}$} & \multirow{2}{*}{$\begin{array}{l}\mathbf{p H} \\
\left(\mathrm{CaCl}_{2}\right)\end{array}$} & \multicolumn{3}{|l|}{ Iron } \\
\hline & & & & & $\begin{array}{l}\text { Clay } \\
(<0.002 \\
\mathrm{mm})\end{array}$ & $\begin{array}{l}\text { Silt } \\
(<0.063 \\
\mathrm{mm})\end{array}$ & $\begin{array}{l}\text { Fine sand } \\
(<0.2 \mathrm{~mm})\end{array}$ & $\begin{array}{l}\text { Med. sand } \\
(<0.63 \mathrm{~mm})\end{array}$ & & & $\begin{array}{l}\mathbf{F e}_{\mathbf{d}} \\
(\mathrm{mg} / \\
100 \mathrm{~g})\end{array}$ & $\begin{array}{l}\mathbf{F e}_{\mathbf{o}} \\
(\mathrm{mg} / \\
100 \mathrm{~g})\end{array}$ & $\begin{array}{l}\mathbf{F e}_{\mathbf{p}} \\
(\mathrm{mg} / \\
100 \mathrm{~g})\end{array}$ \\
\hline $0-14$ & Oh+Aeh & $0 / \mathrm{AE}$ & Mor & 10YR2/1 & - & - & - & - & 77.9 & 3.1 & - & - & - \\
\hline 18 & Aeh & $\mathrm{AE}$ & Aeolian & 7.5YR3/1 & 0.0 & 5.3 & 87.7 & 7.0 & 6.2 & 2.9 & 0.4 & 8.0 & 15.0 \\
\hline 32 & Ahe & EA & sand & $7.5 \mathrm{YR} 6 / 3$ & 0.0 & 4.1 & 88.6 & 7.3 & 0.9 & 3.4 & 0.2 & 0.8 & 3.0 \\
\hline 40 & $\mathrm{Bh}$ & $\mathrm{Bh}$ & & $5 Y R 2.5 / 2$ & 2.7 & 5.0 & 82.1 & 10.2 & 6.5 & 3.4 & 3.5 & 332.0 & 189.0 \\
\hline 44 & Bs & Bs & & $7.5 Y R 5 / 8$ & 0.0 & 4.5 & 86.0 & 9.5 & 2.6 & 4.0 & 2.4 & 267.0 & 29.6 \\
\hline 110 & rGo-Bhs & $\mathrm{BhsCg}$ & & 10YR6/ 6 & 0.0 & 2.6 & 88.6 & 8.8 & 0.6 & 4.3 & 0.8 & 35.9 & 18.1 \\
\hline 190 & rGr1 & $\mathrm{Cr}$ & & $2.5 \mathrm{YR} 6 / 3$ & 0.0 & 2.4 & 89.4 & 8.2 & 0.3 & 4.4 & 1.2 & 5.6 & 4.6 \\
\hline 205 & rGr2 & $\mathrm{Cr}$ & & $5 Y 7 / 3$ & 2.5 & 5.7 & 82.1 & 9.7 & 0.6 & 4.0 & 1.0 & 7.2 & 4.1 \\
\hline 206 & II fAeh & $2 \mathrm{AEb}$ & Glacio- & 10YR2/2 & 5.2 & 15.1 & 77.6 & 2.1 & 11.4 & 3.9 & 1.3 & 5.7 & 2.6 \\
\hline 208 & fAhe & $\mathrm{EAb}$ & lacustrine & 10YR7/3 & 0.0 & 21.4 & 78.2 & 0.4 & 1.8 & 4.0 & 0.8 & 1.7 & 0.4 \\
\hline 213 & $\mathrm{fBh}$ & Bhb & sand & $10 Y R 4 / 4$ & 0.1 & 17.6 & 78.8 & 3.5 & 1.1 & 4.1 & 1.0 & 1.5 & 1.5 \\
\hline $250+$ & $\mathrm{fGr}$ & $\mathrm{Crb}$ & & $2.5 Y 5 / 3$ & 0.0 & 4.8 & 86.9 & 8.3 & 0.4 & 4.3 & 1.1 & 1.8 & 0.8 \\
\hline
\end{tabular}

Surface soil: KA4: Relikt-Gley-Podsol; WRB: (Relic-) Gleyic Podzol

Buried soil: KA4: ('Nano'-) Podsol; WRB: ('Nano'-) Podzol 
Profile AD0 31 (altitude: 3.6 m a.s.l., German coordinates: RW 4534825, HW 6031125; groundwater level 06/2002: c. 250 cm)

\begin{tabular}{|c|c|c|c|c|c|c|c|c|c|c|c|c|c|}
\hline \multirow{2}{*}{$\begin{array}{l}\text { Depth } \\
(\mathrm{cm})\end{array}$} & \multirow{2}{*}{$\begin{array}{l}\text { Horizon } \\
(\mathrm{KA} 4)\end{array}$} & \multirow{2}{*}{$\begin{array}{l}\text { Horizon } \\
\text { (WRB) }\end{array}$} & \multirow{2}{*}{ Substrate } & \multirow{2}{*}{$\begin{array}{l}\text { Colour } \\
\text { (Munsell) }\end{array}$} & \multicolumn{4}{|c|}{ Grain size distribution (\%) } & \multirow{2}{*}{$\begin{array}{l}\text { LOI } \\
(\%)\end{array}$} & \multirow{2}{*}{$\begin{array}{l}\mathbf{p H} \\
\left(\mathrm{CaCl}_{2}\right)\end{array}$} & \multicolumn{3}{|l|}{ Iron } \\
\hline & & & & & $\begin{array}{l}\text { Clay } \\
(<0.002 \\
\mathrm{mm})\end{array}$ & $\begin{array}{l}\text { Silt } \\
(<0.063 \\
\mathrm{mm})\end{array}$ & $\begin{array}{l}\text { Fine sand } \\
(<0.2 \mathrm{~mm})\end{array}$ & $\begin{array}{l}\text { Med. sand } \\
(<0.63 \mathrm{~mm})\end{array}$ & & & $\begin{array}{l}\mathrm{Fe}_{\mathrm{d}} \\
(\mathrm{mg} / \\
100 \mathrm{~g})\end{array}$ & $\begin{array}{l}\mathrm{Fe}_{\mathbf{o}} \\
(\mathrm{mg} / \\
100 \mathrm{~g})\end{array}$ & $\begin{array}{l}\mathbf{F e}_{\mathrm{p}} \\
(\mathrm{mg} / \\
100 \mathrm{~g})\end{array}$ \\
\hline $0-24$ & rGmso-rAp & ApCcs & Aeolian & 10YR3/3 & - & - & - & - & - & 5.4 & - & - & - \\
\hline 30 & rAp-rGkso & CcsAp & sand & $5 Y R 5 / 8$ & - & - & - & - & - & 5.6 & - & - & - \\
\hline 58 & $\mathrm{rGr}$ & $\mathrm{Cr}$ & & $2.5 Y 7 / 2$ & 0.0 & 3.0 & 95.9 & 1.1 & 0.2 & 5.7 & - & - & - \\
\hline 76 & foM & $\mathrm{CAb}$ & & $10 \mathrm{YR} 5 / 3$ & 0.8 & 4.7 & 93.2 & 1.3 & 2.7 & 5.4 & - & - & - \\
\hline 84 & II rGo-fAh & $2 \mathrm{AhbCg}$ & Glacio- & 10YR2/2 & 1.3 & 23.4 & 75.1 & 0.2 & 6.0 & 5.3 & - & - & - \\
\hline 90 & fAh & Ahb & lacustrine & $2.5 Y 5 / 2$ & 1.7 & 25.6 & 70.9 & 1.8 & 1.8 & 5.4 & - & - & - \\
\hline 126 & frGr & $\mathrm{Crb}$ & sand & 10YR7/2 & 0.0 & 3.5 & 90.4 & 6.1 & 0.2 & 5.5 & - & - & - \\
\hline 140 & frGo & $\mathrm{Cgb}$ & & $2.5 Y 6 / 6$ & 0.0 & 4.2 & 92.7 & 3.1 & 0.2 & 5.6 & - & - & - \\
\hline 150 & $\mathrm{frGr}$ & $\mathrm{Crb}$ & & $10 Y R 7 / 2$ & 0.0 & 5.5 & 93.2 & 1.3 & 0.3 & 6.8 & - & - & - \\
\hline $250+$ & $\mathrm{fGr}$ & $\mathrm{Crb}$ & & $2.5 Y 6 / 3$ & - & - & - & - & - & - & - & - & - \\
\hline
\end{tabular}

Surface soil: KA4: Relikt-Brauneisengley; WRB: (Relic) Ferric Gleysol

Buried soil: KA4: Gley; WRB: Gleysol

\section{Micromorphology}

Nine undisturbed samples were collected with modified Kubiëna tins $(4.5 \times 2.5 \times 2.5 \mathrm{~cm})$ from profile AD0 $42(221-270 \mathrm{~cm})$. The blocks were air dried, impregnated with Palatal P80-21 and sliced into $4.0 \times 2.4 \mathrm{~cm}$ thin sections. Thin sections were described at 25 - 400x magnification under a petrological microscope mainly using the terminology of Stoops (2003).

\section{Radiocarbon dating}

Three radiocarbon samples were taken from the $\mathrm{fH}$ horizon in AD0 39. Hv-24639 is dated conventionally using coniferous wood (probably pine). Poz-2212 and Poz-3207 are AMS dated using birch fruits (probably Betula pubescens) and remains of the moss Polytrichum spec., respectively. Both macro remain (AMS) samples were treated chemically before selection (10\% $\mathrm{KOH})$. The radiocarbon ages discussed in the text are mostly uncalibrated $\left({ }^{14} \mathrm{C}\right.$-years before present $\left.=\mathrm{BP}\right)$. Any comparison with OSL ages, however, have to be based on the calibrated radiocarbon ages (cal BP-values). The calibration of the own data is based on the radiocarbon calibration program CALIB Rev 5.0.1 (Stuiver \& Reimer, 2005).

\section{Luminescence dating}

Detailed principles and different protocols used for OSL dating have been summarised by Aitken (1998). All luminescence measurements were carried out on the purified quartz fraction in the grain size range of $0.1-0.2 \mathrm{~mm}$ following the singlealiquot regenerative-dose protocol ('SAR'; Murray \& Wintle, 2000). To calculate the annual dose derived from the decay of lithogenic radionuclides in the sediment, the concentration of uranium, thorium, and potassium was determined by neutron activation analysis (NAA, analysed by Becquerel Laboratories, Sydney, Australia). In addition, for some samples radionuclide contents have been determined by gamma-spectrometry.

\section{Dendrology}

Twenty samples of woods from the profiles AD0 1, AD0 31, and ADO 39 were determinated by $\mathrm{H}$. Süß (Potsdam) using a reference collection and literature (Schweingruber, 1990).

\section{Palynology}

Single samples were taken from the buried soils at AD0 1, AD0 7, $A D 031$, and $A D 0$ 39. Furthermore, two longer sections from profiles ADO 39 and ADO 40 were sampled comprising 60 and $40 \mathrm{~cm}$ in length, respectively. Sample preparation after Faegri \& Iversen (1989) included treatment with $\mathrm{HCl}, 20 \% \mathrm{KOH}$, sieving $(120 \mu \mathrm{m})$ and acetolysis (7 min). Additionally, samples rich in silicates were treated with HF. Samples were mounted in silicone oil. Counting was carried out with 400x magnification. Percentages are calculated based on upland pollen sum (excluding Cyperaceae), including pollen types attributed to trees and herbs from terrestrial sites.

\section{Macrofossil analysis}

Samples were taken from profiles $\operatorname{AD0} 1, \operatorname{AD0} 7, \operatorname{AD0} 31$, and ADO 39 (volume: $250 \mathrm{ml}$ ). Treatment of samples included 10 minutes boiling with $10 \% \mathrm{KOH}$ and sieving in 3 fractions (>1 mm, >0.5 mm, >0.2 mm). For analysis, a stereo microscope (5 - 50x magnification) and a microscope (100 - 400x magnification) was used. The abundance of non-countable macrofossil types was estimated in categories. Percentages are recalculated to the sample volume after processing. 
Table 2. Pedological parameters of profiles $A D O$ 39, ADO 40, and ADO 42 (analysis: K. Kaiser \& S. Czakó Pap).

Profile AD0 39 (former profile AD 1; altitude: 5.0 m a.s.l.; German coordinates: RW 4534200, HW 6030100; groundwater level 06/2002: c. 250 cm)

\begin{tabular}{|c|c|c|c|c|c|c|c|c|c|c|c|c|c|}
\hline Depth & & Horizon & Substrate & & Grain si & e distrib & ution (\%) & & & & Iron & & \\
\hline$(\mathrm{cm})$ & (KA4) & (WRB) & & (Munsell) & $\begin{array}{l}\text { Clay } \\
(<0.002 \\
\mathrm{mm})\end{array}$ & $\begin{array}{l}\text { Silt } \\
(<0.063 \\
\mathrm{mm})\end{array}$ & $\begin{array}{l}\text { Fine sand } \\
(<0.2 \mathrm{~mm})\end{array}$ & $\begin{array}{l}\text { Med. sand } \\
(<0.63 \mathrm{~mm})\end{array}$ & $(\%)$ & $\left(\mathrm{CaCl}_{2}\right)$ & $\begin{array}{l}\mathbf{F e}_{\mathbf{d}} \\
(\mathrm{mg} / \\
100 \mathrm{~g})\end{array}$ & $\begin{array}{l}\mathbf{F e}_{\mathbf{o}} \\
(\mathrm{mg} / \\
100 \mathrm{~g})\end{array}$ & $\begin{array}{l}\mathrm{Fe}_{\mathbf{p}} \\
(\mathrm{mg} / \\
100 \mathrm{~g})\end{array}$ \\
\hline+17 & Of, Oh & 0 & Mor & $5 Y R 2.5 / 2$ & - & - & - & - & 94.0 & 2.7 & - & - & - \\
\hline $0-18$ & $\mathrm{Ha}$ & $\mathrm{H}$ & Peat & 10YR2/1 & - & - & - & - & 86.4 & 2.8 & - & - & - \\
\hline 24 & II fAeh & $2 \mathrm{AEb}$ & Aeolian & $7.5 Y R 2.5 / 3$ & 0.0 & 7.9 & 91.0 & 1.1 & 7.9 & 2.9 & $<0.2$ & 10.5 & 12.1 \\
\hline 40 & $\mathrm{fBh}$ & Bhb & sand & $5 Y R 2.5 / 2$ & 1.3 & 7.2 & 90.3 & 1.2 & 13.0 & 3.0 & $<0.2$ & 5.4 & 5.4 \\
\hline 49 & $\mathrm{fBsh} 1$ & Bshb & & 5YR3/4 & 0.2 & 6.4 & 91.3 & 2.1 & 4.7 & 3.3 & $<0.2$ & 2.9 & 3.3 \\
\hline 84 & fBsh-rGo & BshbCg & & $10 Y R 6 / 8$ & 0.4 & 2.7 & 91.3 & 5.6 & 1.1 & 4.0 & 0.3 & 2.0 & 2.6 \\
\hline 99 & $\mathrm{fBsh} 2$ & Bshb & & $2.5 \mathrm{Y} 6 / 4$ & 1.6 & 3.6 & 90.0 & 4.8 & 1.8 & 4.0 & 0.4 & 1.7 & 2.7 \\
\hline 120 & foM & $\mathrm{CAb}$ & & $2.5 \mathrm{Y} 6 / 4$ & 0.5 & 3.6 & 93.3 & 2.0 & 1.3 & 4.2 & 0.6 & $<0.2$ & 1.9 \\
\hline 122 & III $\mathrm{fH}$ & $3 \mathrm{Hb}$ & Peat & 7.5 YR2.5/3 & 3.8 & 61.2 & 30.9 & 4.1 & 58.6 & 3.9 & 28.2 & 66.9 & 27.6 \\
\hline 126 & IV fAhe & $4 \mathrm{EAb}$ & Glacio- & $10 Y R 5 / 4,6 / 2$ & 0.8 & 14.6 & 84.2 & 0.4 & 2.0 & 4.2 & 0.3 & $<0.2$ & 1.2 \\
\hline 136 & fBh-rGr & $\mathrm{BhbCr}$ & lacustrine & $2.5 Y 5 / 4$ & 0.0 & 5.3 & 90.7 & 4.0 & 0.6 & 4.3 & 0.8 & 0.5 & 1.5 \\
\hline $180+$ & frGr & $\mathrm{Crb}$ & sand & $5 Y 5 / 3$ & - & - & - & - & - & - & - & - & - \\
\hline
\end{tabular}

Surface soil: KA4: Relikt-Moor-Podsol; WRB: (Relic-) Histic Podzol

Buried soil: KA4: schwach podsolierter Moorgley; WRB: weakly podzolized Histic Gleysol

Profile ADO 40 (former profile AD 2; altitude: 4.5 m a.s.l.; German coordinates: RW 4534575, HW 6030350; groundwater level 06/2002: c. 250 cm)

\begin{tabular}{|c|c|c|c|c|c|c|c|c|c|c|c|c|c|}
\hline & & & Substrate & & Grain si & ze distrib & ution $(\%)$ & & & & Iron & & \\
\hline$(\mathrm{cm})$ & (KA4) & (WRB) & & (Munsell) & $\begin{array}{l}\text { Clay } \\
(<0.002 \\
\mathrm{mm})\end{array}$ & $\begin{array}{l}\text { Silt } \\
(<0.063 \\
\mathrm{mm})\end{array}$ & $\begin{array}{l}\text { Fine sand } \\
(<0.2 \mathrm{~mm})\end{array}$ & $\begin{array}{l}\text { Med. sand } \\
(<0.63 \mathrm{~mm})\end{array}$ & $(\%)$ & $\left(\mathrm{CaCl}_{2}\right)$ & $\begin{array}{l}\mathrm{Fe}_{\mathrm{d}} \\
(\mathrm{mg} / \\
100 \mathrm{~g})\end{array}$ & $\begin{array}{l}\mathrm{Fe}_{\mathbf{o}} \\
(\mathrm{mg} / \\
100 \mathrm{~g})\end{array}$ & $\begin{array}{l}\mathrm{Fe}_{\mathrm{p}} \\
(\mathrm{mg} / \\
100 \mathrm{~g})\end{array}$ \\
\hline+12 & Of, Oh & 0 & Mor & See verbal & - & - & - & - & 63.8 & 2.7 & - & - & - \\
\hline $0-12$ & Aeh+Ahe & $\mathrm{AE} / \mathrm{EA}$ & Aeolian & description & 0.0 & 6.2 & 88.9 & 4.9 & 1.8 & 3.2 & - & - & - \\
\hline 17 & $\mathrm{Bh}$ & $\mathrm{Bh}$ & sand & in Kaiser & 0.9 & 8.1 & 84.7 & 6.3 & 9.9 & 2.9 & - & - & - \\
\hline 28 & Bsh & Bsh & & (2001) & 4.6 & 5.8 & 84.4 & 5.2 & 11.2 & 3.4 & - & - & - \\
\hline 38 & Bhs & Bhs & & & 1.4 & 3.8 & 87.2 & 7.6 & 4.4 & 3.8 & - & - & - \\
\hline 78 & rGo-Bs & $\mathrm{BsCg}$ & & & 0.0 & 3.3 & 91.9 & 4.8 & 1.2 & 4.2 & - & - & - \\
\hline 148 & $\mathrm{rGr}$ & $\mathrm{Cr}$ & & & 0.0 & 2.0 & 91.8 & 6.2 & 0.4 & 4.5 & - & - & - \\
\hline 154 & foM-rGr & $\mathrm{CAbCr}$ & & & 0.5 & 2.7 & 89.4 & 7.4 & 0.7 & 4.2 & - & - & - \\
\hline 170 & frGr & $\mathrm{Crb}$ & & & - & - & - & - & - & - & - & - & - \\
\hline 176 & foM & $\mathrm{CAb}$ & & & 0.6 & 3.8 & 91.1 & 4.5 & 0.9 & 4.1 & - & - & - \\
\hline 200 & frGr & $\mathrm{Crb}$ & & & - & - & - & - & - & - & - & - & - \\
\hline 210 & fGo-oM1 & $\mathrm{CAbCg}$ & & & 0.0 & 3.5 & 89.1 & 7.4 & 0.7 & 4.1 & - & - & - \\
\hline 225 & fGo-oM2 & $\mathrm{CAbCg}$ & & & 0.6 & 4.3 & 89.9 & 5.2 & 1.4 & 3.8 & - & - & - \\
\hline 237 & II $\mathrm{fGo}-\mathrm{Hr}$ & $2 \mathrm{HbGg}$ & Peat & & 3.8 & 55.9 & 38.2 & 2.1 & 61.5 & 3.6 & - & - & - \\
\hline 255 & III fF-Gr1 & $3 \mathrm{Crb}$ & Gyttja & & 0.6 & 22.7 & 75.7 & 1.0 & 5.4 & 3.3 & - & - & - \\
\hline 263 & $\mathrm{fF}-\mathrm{Gr} 2$ & $\mathrm{Crb}$ & & & 0.4 & 9.6 & 83.9 & 6.1 & 0.7 & 3.5 & - & - & - \\
\hline $290+$ & IV fGr & $4 \mathrm{Crb}$ & $\begin{array}{l}\text { Glacio- } \\
\text { lac. sand }\end{array}$ & & 0.0 & 6.0 & 89.2 & 4.8 & 0.3 & 3.6 & - & - & - \\
\hline
\end{tabular}

Surface soil: KA4: Relikt-Gley-Podsol; WRB: (Relic-) Gleyic Podzol

Buried soil: Moorgley (KA4); Histosol (WRB) 
Profile AD0 42 (former profile AD 4; altitude: $6.2 \mathrm{~m}$ a.s.l.; German coordinates: RW 4534625, HW 6031675; groundwater level 06/1999: >400 cm)

\begin{tabular}{|c|c|c|c|c|c|c|c|c|c|c|c|c|c|}
\hline \multirow{2}{*}{$\begin{array}{l}\text { Depth } \\
(\mathrm{cm})\end{array}$} & \multirow{2}{*}{$\begin{array}{l}\text { Horizon } \\
(\mathrm{KA} 4)\end{array}$} & \multirow{2}{*}{$\begin{array}{l}\text { Horizon } \\
(\text { WRB })\end{array}$} & \multirow[t]{2}{*}{ Substrate } & \multirow{2}{*}{$\begin{array}{l}\text { Colour } \\
\text { (Munsell) }\end{array}$} & \multicolumn{4}{|c|}{ Grain size distribution (\%) } & \multirow{2}{*}{$\begin{array}{l}\text { LOI } \\
(\%)\end{array}$} & \multirow{2}{*}{$\begin{array}{l}\mathbf{p H} \\
\left(\mathrm{CaCl}_{2}\right)\end{array}$} & \multicolumn{3}{|l|}{ Iron } \\
\hline & & & & & $\begin{array}{l}\text { Clay } \\
(<0.002 \\
\mathrm{mm})\end{array}$ & $\begin{array}{l}\text { Silt } \\
(<0.063 \\
\mathrm{mm})\end{array}$ & $\begin{array}{l}\text { Fine sand } \\
(<0.2 \mathrm{~mm})\end{array}$ & $\begin{array}{l}\text { Med. sand } \\
(<0.63 \mathrm{~mm})\end{array}$ & & & $\begin{array}{l}\mathbf{F e}_{\mathbf{d}} \\
(\mathrm{mg} / \\
100 \mathrm{~g})\end{array}$ & $\begin{array}{l}\mathbf{F e}_{\mathbf{o}} \\
(\mathrm{mg} / \\
100 \mathrm{~g})\end{array}$ & $\begin{array}{l}\mathrm{Fe}_{\mathbf{p}} \\
(\mathrm{mg} / \\
100 \mathrm{~g})\end{array}$ \\
\hline+20 & $\mathrm{Of}, \mathrm{Oh}$ & 0 & Mor & See verbal & - & - & - & - & - & - & - & - & - \\
\hline $0-25$ & Aeh, Ahe & $\mathrm{AE}, \mathrm{EA}$ & Aeolian & description & 1.5 & 10.4 & 70.2 & 17.9 & 2.1 & 2.9 & - & - & - \\
\hline 31 & Bsh & Bsh & sand & in Kaiser & 1.1 & 13.4 & 67.4 & 18.1 & 12.3 & 3.0 & - & - & - \\
\hline 58 & Bsh-rGo1 & CgBsh & & (2001) & 2.2 & 7.2 & 66.1 & 24.5 & 1.4 & 4.2 & - & - & - \\
\hline 100 & Bsh-rGo2 & $\mathrm{CgBsh}$ & & & 1.5 & 3.7 & 71.2 & 23.6 & 0.7 & 4.2 & - & - & - \\
\hline 150 & rGo & $\mathrm{Cg}$ & & & 2.0 & 4.9 & 69.7 & 23.4 & 0.4 & 4.1 & - & - & - \\
\hline 200 & rGo & $\mathrm{Cg}$ & & & 1.4 & 3.7 & 71.7 & 23.2 & 0.2 & 4.0 & - & - & - \\
\hline 244 & rGo & $\mathrm{Cg}$ & & & 1.7 & 4.3 & 66.6 & 27.4 & 0.2 & 4.0 & - & - & - \\
\hline 253 & II fAeh1 & $2 \mathrm{AEb}$ & Aeolian & & 6.0 & 19.9 & 73.8 & 0.3 & 3.9 & 3.4 & - & - & - \\
\hline 257 & fAeh2 & $\mathrm{AEb}$ & sand & & 3.0 & 32.8 & 63.9 & 0.3 & 3.0 & 3.5 & - & - & - \\
\hline 265 & III $\mathrm{frGr}$ & $3 \mathrm{Crb}$ & Glacio- & & 3.1 & 19.1 & 65.7 & 12.1 & 0.6 & 3.8 & - & - & - \\
\hline 300 & $\mathrm{frGr}$ & $\mathrm{Crb}$ & lacustrine & & 1.4 & 5.5 & 69.9 & 23.2 & 0.2 & 4.0 & - & - & - \\
\hline 350 & $\mathrm{frGr}$ & $\mathrm{Crb}$ & sand & & 1.3 & 4.7 & 71.0 & 23.0 & 0.2 & 4.0 & - & - & - \\
\hline $400+$ & frGr & $\mathrm{Crb}$ & & & 1.2 & 3.9 & 74.5 & 20.4 & 0.2 & 3.8 & - & - & - \\
\hline
\end{tabular}

Surface soil: KA4: Relikt-Gley-Podsol; WRB: (Relic-) Gleyic Podzol

Buried soil: KA4: schwach podsoliger Regosol; WRB: weakly podzolized Dystric Arenosol

\section{Results}

\section{Pedology}

A reliable classification of the buried soils was only successful for those profiles that were accessible in trenches and analysed by several methods. Uncertainties remain in the majority of the cores, especially in those with peats and gyttjas. Furthermore, the assumption that the sands immediately below the buried soils are of glaciolacustrine origin is hypothetical. This opinion is based on the present state of the art of geological research in the Altdarss area: The relatively high content of silt (14.6 - 32.8\%) in the upper part of these sands might have been caused by aeolian sedimentation as well. The recent relief consisting of longitudinal dunes, deflation hollows, and a gently undulating overall relief clearly indicates that the sands above the buried soil are of aeolian origin. They are dominated by fine sand particles ranging from $0.063-0.2 \mathrm{~mm}$ (general grain-size distribution: medium sand $=1.1-27.4 \%$, fine sand $=66.1-95.9 \%$, silt $=$ $2.0-13.4 \%$, clay $=0.0-4.6 \%$ ). Geomorphological evidence from the adjacent Barther Heide area (same pedostratigraphy, sand sheets with high-angle cross lamination of $24-36^{\circ}$ to SE) points to an aeolian facies of the upper sands as well (Kaiser, 2001).

\section{ADO 39}

The buried soil is covered by only ca. $100 \mathrm{~cm}$ of aeolian sand (Figs 2, 3, 4a, 4b, Table 2). Since the present groundwater level was recorded in a depth of ca. $250 \mathrm{~cm}$, the peat horizon in between the mor layer and the aeolian sands indicates a substantial lowering of the groundwater level. In the lower part of the aeolian sand several conspicuous illuviation bands occur; they consist of humic matter. A thin organic horizon ('foM', LOI: $1.0 \%$ ) was found immediately above the buried soil. It is interpreted as material from the buried soil below, which was translocated by wind. Since such horizon formed by aeolian relocation had not yet been suitably named, a new designation was created for it: 'oM/foM' (prefix o from aeolian, $M$ from migrare). The buried soil itself is $6 \mathrm{~cm}$ thick and divided into an upper organic horizon ( $\mathrm{fH}$ ) and a lower minerogenic horizon (mostly fAhe, partly fAeh). Both the profile and the plan show a wavy shape of the buried soil surface. While the thickness is constant, the surface is undulating strongly, with highest amplitude of $43 \mathrm{~cm}$. The undulations may reflect a periglacial movement of the ground or are a result of the pressure of the overlying sands. Large remains of birch and coniferous wood (probably pine) occur in the $\mathrm{fH}$ horizon. The dominating component of this horizon is silt $(61.2 \%)$, LOI is high $(58.6 \%)$. The high amount of iron can be explained by the 'trap-effect' of organic matter. The iron originates most probably from the podzolized sands above. The dominance of Sphagnum-moss and the low amount of fine litter of wood indicate that this horizon predominately consists of peat. Following a standard for construction grounds (DIN V 4019100,1996 ), the original thickness was $2.1 \mathrm{~cm}$ (pers. comm. K. Krienke, Stralsund). Similar results with only a little increase in thickness of the peat were obtained for the other profiles (AD0 1: $6.0 \mathrm{~cm} \rightarrow 6.5 \mathrm{~cm}$, AD0 40: $12.0 \mathrm{~cm} \rightarrow 16.4 \mathrm{~cm}$ ). The underlying fAhe horizon is dominated by sand (84.6\%) and has a relatively low organic content (LOI: $2.0 \%$ ). A following $\mathrm{fBh}-\mathrm{rGr}$ horizon is only weakly developed. 


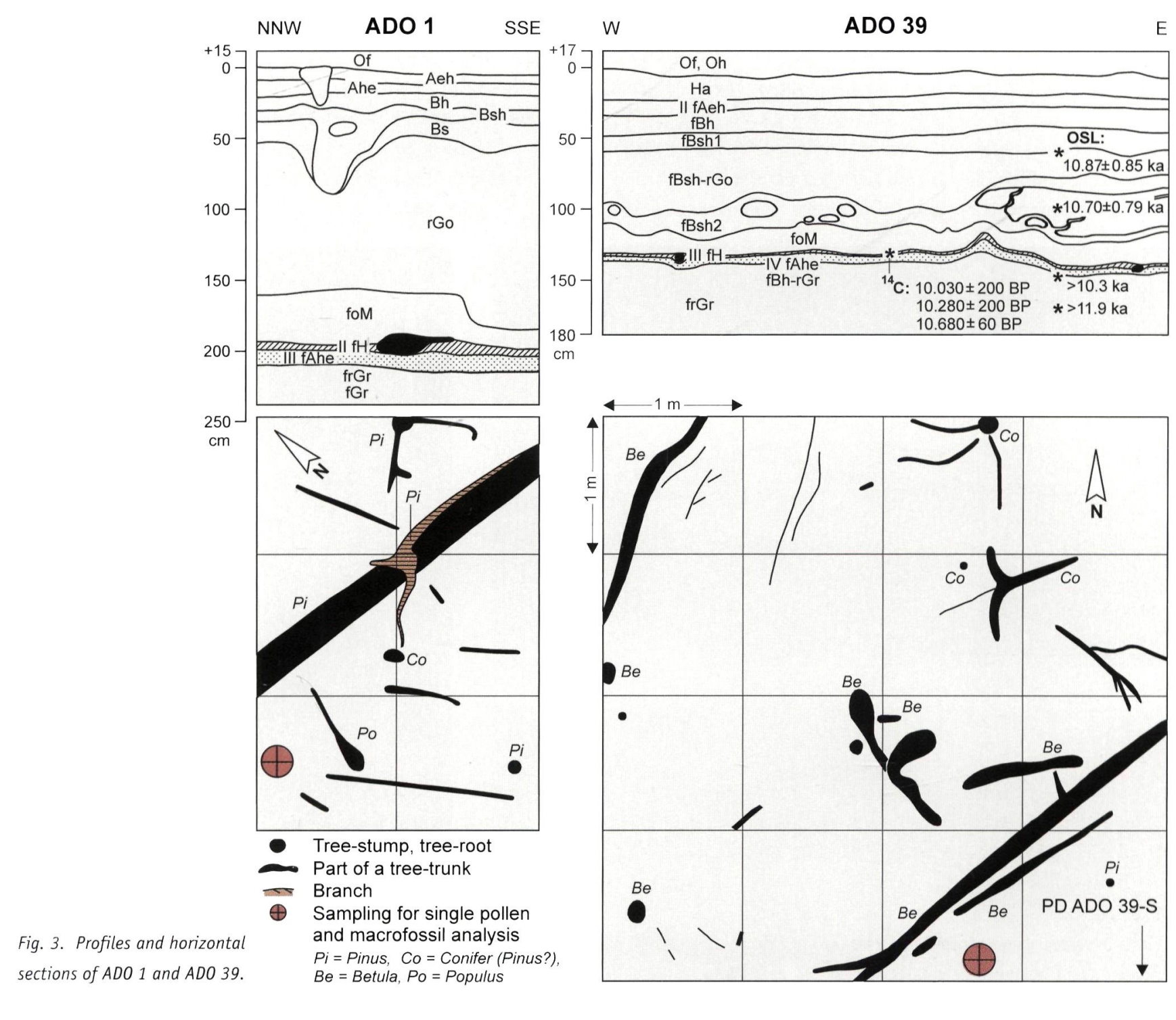

This profile is very similar to AD0 39 (Figs 2, 3, 4c, 4d, Table 1). The buried soil occurs in a depth of $195-211 \mathrm{~cm}$. It comprises an upper fH horizon (LOI: $60.5 \%$, silt: $49.1 \%$ ) and a lower fAhe horizon (LOI: $2.7 \%$, silt: $18.4 \%$ ). The $\mathrm{fH}$ horizon is rich in $\mathrm{Fe}$ due to infiltration of humic acids with percolating soil water from the surface. Large remains of pine wood were found in the $\mathrm{fH}$ horizon.

\section{ADO 40}

The buried soil is situated in a low relief position (ca. $2.2 \mathrm{~m}$ a.s.l.) and it is classified as a Histosol. It occurs in a depth of 225 - 237 cm (LOI: $61.5 \%$, silt: 55.9\%; Figs 2, 4e, Table 2). A sandy gyttja was found below the buried soil (LOI: $0.7-5.4 \%$ ) indicating the former existence of a pond. In contrast to the other profiles, profile ADO 40 contains several foM horizons. Consequently, the aeolian covering took place locally in several short episodes.
Two fAeh horizons in a depth of $244-257 \mathrm{~cm}$ form the buried soil (LOI: 3.0 - 3.9\%, silt: 19.9 - 32.8\%; Figs 2, 4f, 4g, Table 2). Both horizons show a distinct horizontal layering indicating soil formation during input of drifting sands. Furthermore, it points to a low intensity of syngenetic bioturbation. The soil is classified as weakly podzolized Dystric Arenosol.

ADO 31

This profile is situated in a long and shallow depression. Two (rGo-)fAh horizons are covered by an only $79 \mathrm{~cm}$ thick cover of aeolian sand (LOI: $1.8-6.0 \%$, silt: $23.4-25.6 \%$; Figs 2, 4h, Table 1). Because of the low content of organic matter and the situation in the relief it is classified as a Gleysol. Remains of alder in the buried soil originate from the surface of the modern soil. 
analysis supports this assumption (see further). However, the buried soil is situated in the lowest position of all profiles

The buried soil is formed by an $8 \mathrm{~cm}$ thick fAeh-fAhe-fBh sequence (LOI: $1.1-11.4 \%$, silt: $15.1-21.4 \%$; Figs 2, 4i, Table 1). It is classified as a weakly developed ('Nano'-) Podzol. Macrofossil analysis points to a high degree of decomposition of the organic matter due to dry site conditions; pollen investigated (ca. $1.6 \mathrm{~m}$ a.s.l.). This could be explained by a change in altitude after soil formation. Taking the position of the profile close to a large depression into account (Fig. 1), the melting of buried dead ice might have been responsible for that phenomenon.
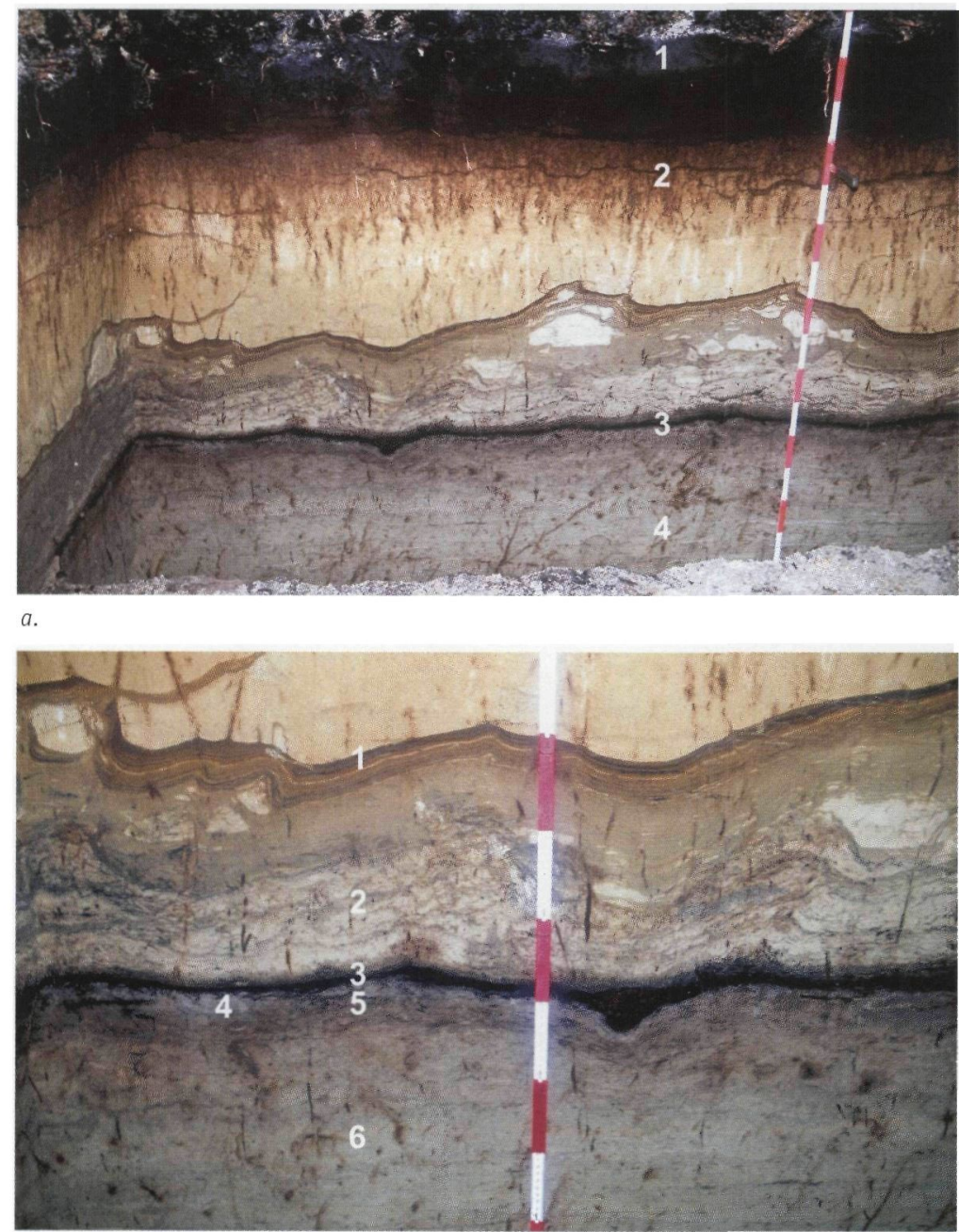

b.

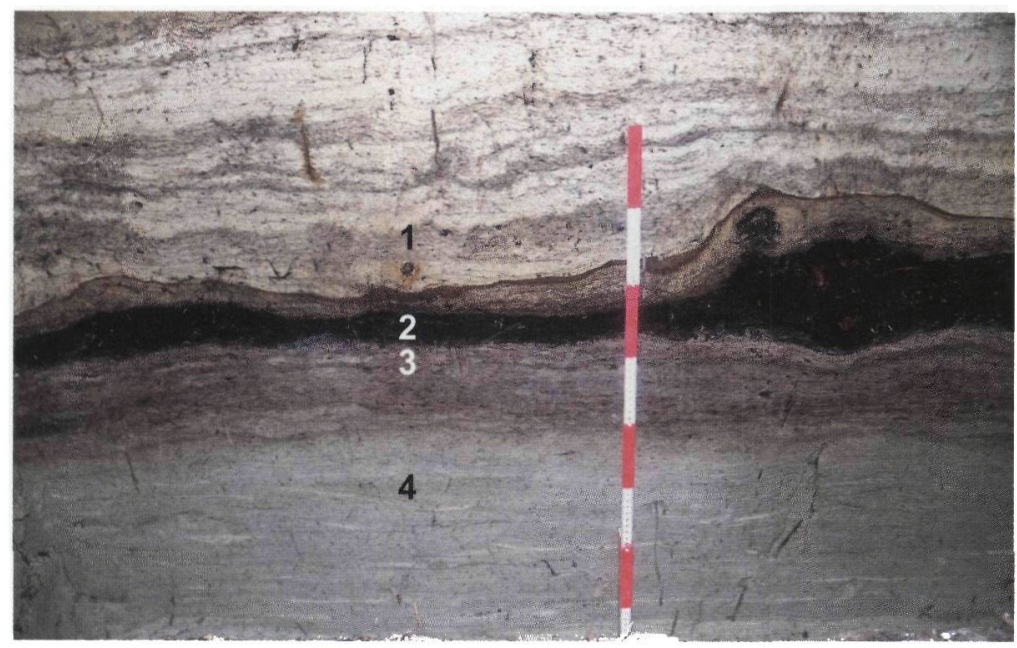

d.

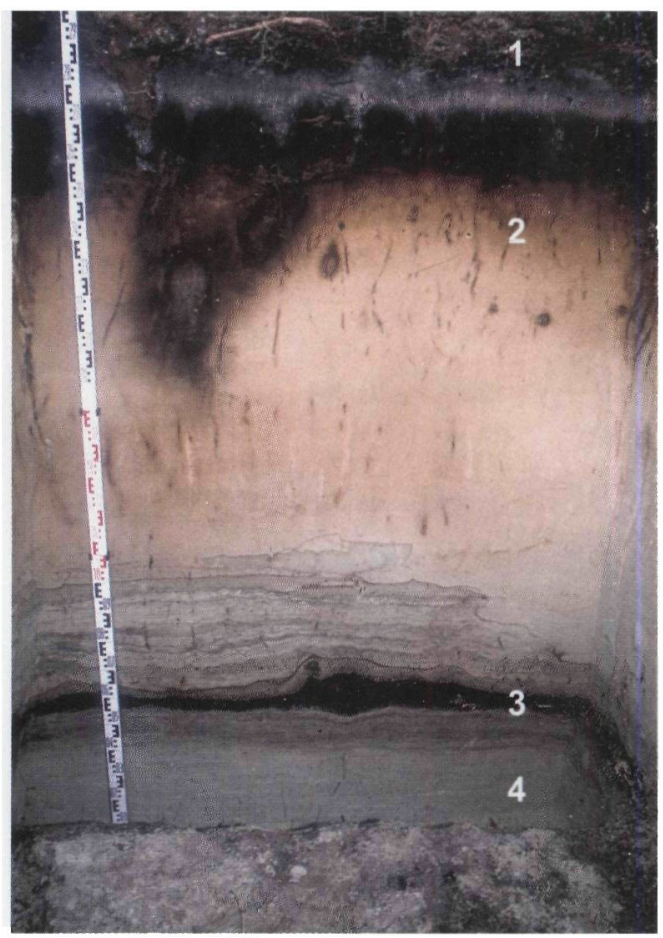

c.

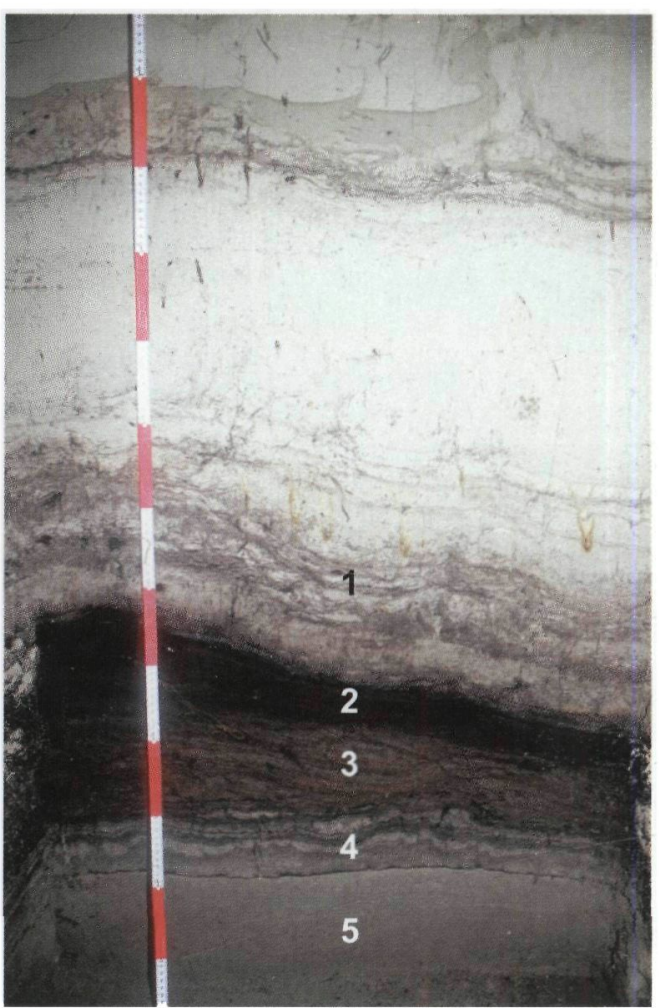




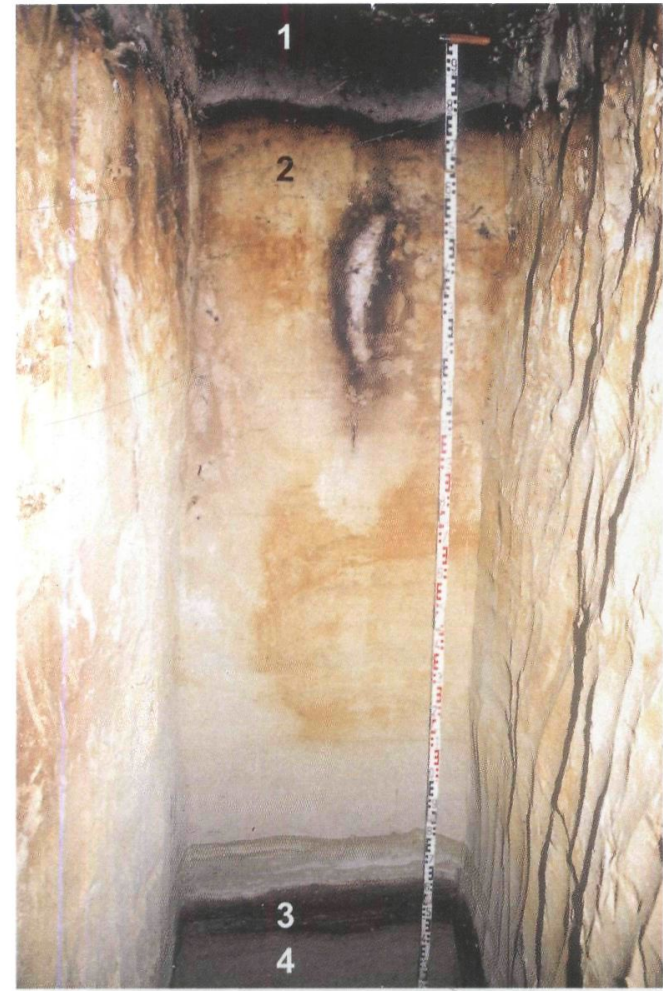

f.

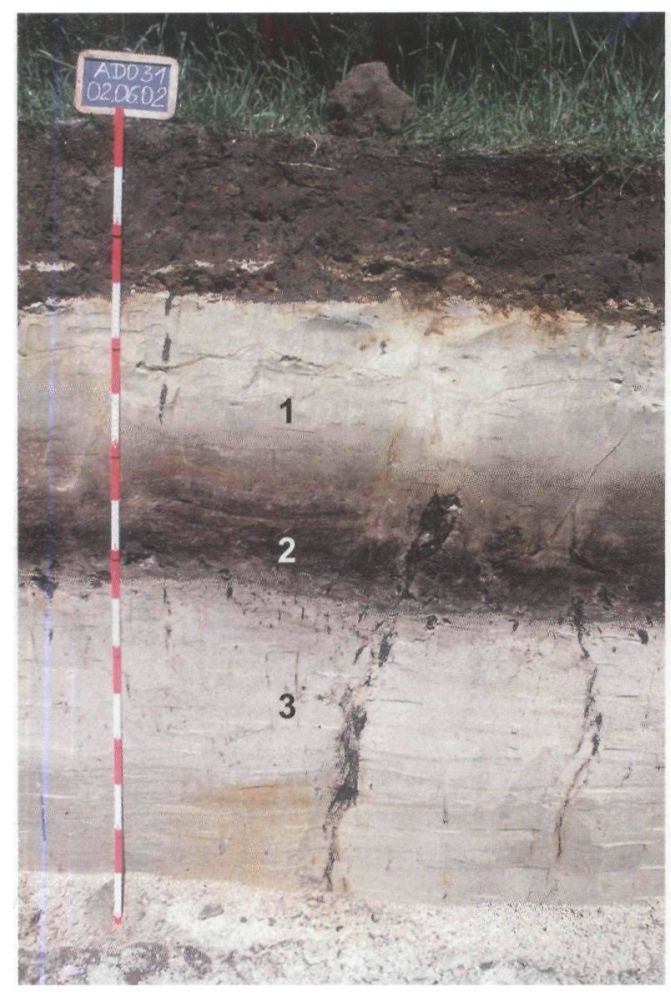

h.

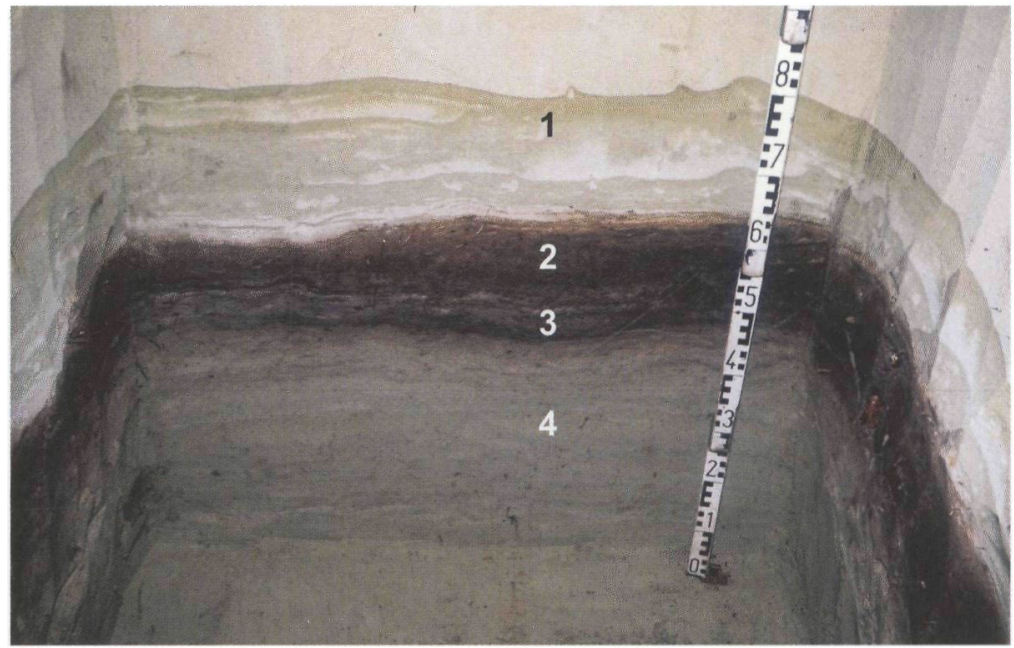

g.

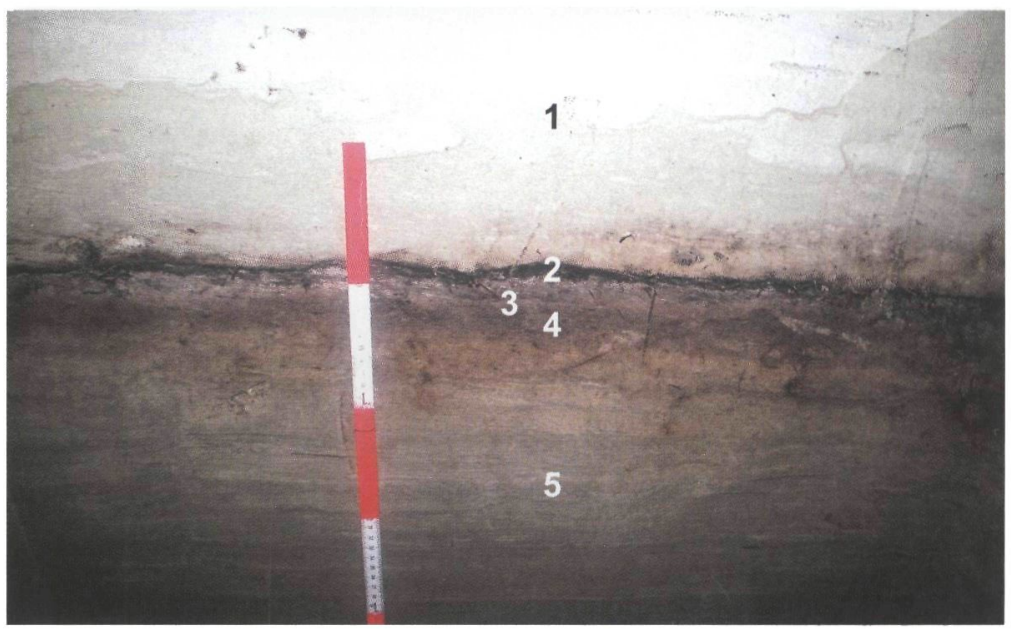

i.

Fig. 4. Photos of the profiles investigated (photos: K. Kaiser); a. All-up view of profile ADO 39: 1 - peat, 2 - aeolian sand with (Relic-) Gleyic Podzol (gleyic properties masked), 3 - buried Lateglacial soil (weakly podzolized Histic Gleysol), 4 glaciolacustrine sand; b. Close-up view of the buried Lateglacial soil in Profile ADO 39: 1 - fBsh2 horizon (aeolian sand), 2 - foM horizon (aeolian sand), 3 - fH horizon (peat), 4 - fAhe horizon (glaciolacustrine sand), 5 - $f B h-r G r$ horizon (glaciolacustrine sand), 6 - frGr horizon (glaciolacustrine sand); c. All-up view of profile ADO 1: 1 - mor cover, 2 - aeolian sand with (Relic-) Gleyic Podzol, 3 - buried Lateglacial soil (weakly podzolized Histic Gleysol), 4 - glaciolacustrine sand; $d$. Close-up view of the buried Lateglacial soil in Profile ADO 1: 1 - foM horizon (aeolian sand), 2 - fH horizon (peat), 3 - fAhe horizon (glaciolacustrine sand), 4 frGr horizon (glaciolacustrine sand); e. Close-up view of the buried Lateglacial soil in Profile ADO 40 (Histosol): 1 - fGo-OM horizon (aeolian sand), 2 - fGo-Hr horizon (peat), 3 - fF-Gr1 (gyttja), 4 - fF-Gr2 (gyttja), 5 - fGr (glaciolacustrine sand); f. All-up view of profile ADO 42: 1 - mor cover, 2 - aeolian sand with (Relic-) Gleyic Podzol, 3 - buried Lateglacial soil (weakly podzolized Dystric Arenosol), 4 - glaciolacustrine sand; $g$. Close-up view of the buried Lateglacial soil in Profile ADO 42: 1 - rGo horizon (aeolian sand), 2 - fAeh1 horizon (aeolian sand), 3 - fAeh2 horizon (aeolian sand), 4 - frGr horizon (glaciolacustrine sand); h. All-up view of profile ADO 31: 1 - aeolian sand with (Relic-) Ferric Gleysol, 2 - buried Lateglacial soil with rGo-fAh and fAh horizon (Gleysol), 3 - glaciolacustrine sand; i. Close-up view of the buried Lateglacial soil in Profile ADO 7 ('Nano'-Podzol): 1 - rGr horizon (aeolian sand), 2 - fAeh horizon (glaciolacustrine sand?), 3 -fAhe horizon (glaciolacustrine sand?), 4 - fBh horizon (glaciolacustrine sand?), 5 - fGr horizon (glaciolacustrine sand). 


\section{Micromorphology}

The option of a micromorphological characterisation of a buried soil was given only for the weakly podzolized Dystric Arenosol (AD0 42), which is situated in the highest position of the palaeotransect.

\section{rGo horizon $(200-244 \mathrm{~cm}$, lower $15 \mathrm{~cm})$}

Mineral grains are subangular to rounded, only some angular. Grain size varies from $50-300 \mu \mathrm{m}$. Numerous grains are surrounded by a hem of oriented clay or linked by concave yellow-brown clay bridges (Fig. 5a). Organic matter is absent above $10 \mathrm{~cm}$ from the upper boundary of the fAeh1 horizon. A small amount of organic matter was detected in $2-5 \mathrm{~cm}$ above the fAeh1 horizon. Longitudinal plant residues are layered horizontally. The degree of decomposition of the organic matter is low. The sharp boundary to the fAeh1 horizon lies within $0.5 \mathrm{~cm}$.
fAeh horizons $(244-257 \mathrm{~cm})$

Mineral grains are subangular to rounded, only some angular. Grain size varies between $60-200 \mu \mathrm{m}$ in the upper $5 \mathrm{~cm}$ and between $60-150 \mu \mathrm{m}$ in the lower $15 \mathrm{~cm}$. Translocation features are hardly detectable. Few minerals are surrounded by a hem of oriented clay $(<10 \mu \mathrm{m})$. Longitudinal plant residues are layered horizontally (Fig 5b). Rounded peds of reddish brown organic matter (diameter ca. $100 \mu \mathrm{m}$ ) occur particularly in the lower $5 \mathrm{~cm}$. These peds show a high degree of decomposition, whereas roots and remains of roots are weakly deformed (Fig. 5c). Nearly no fine mineral components are present. Biotites are weakly bleached.

\section{frGr horizon (257 - $265 \mathrm{~cm})$}

Layers of coarser fractions (100 - $200 \mu \mathrm{m}$, partially up to $250 \mu \mathrm{m})$ alternate with layers of finer fractions (50-100 $\mu \mathrm{m})$. The thickness of each layer is $5 \mathrm{~mm}$. The grains are angular or subrounded, some rounded. Nearly no fine material is present.

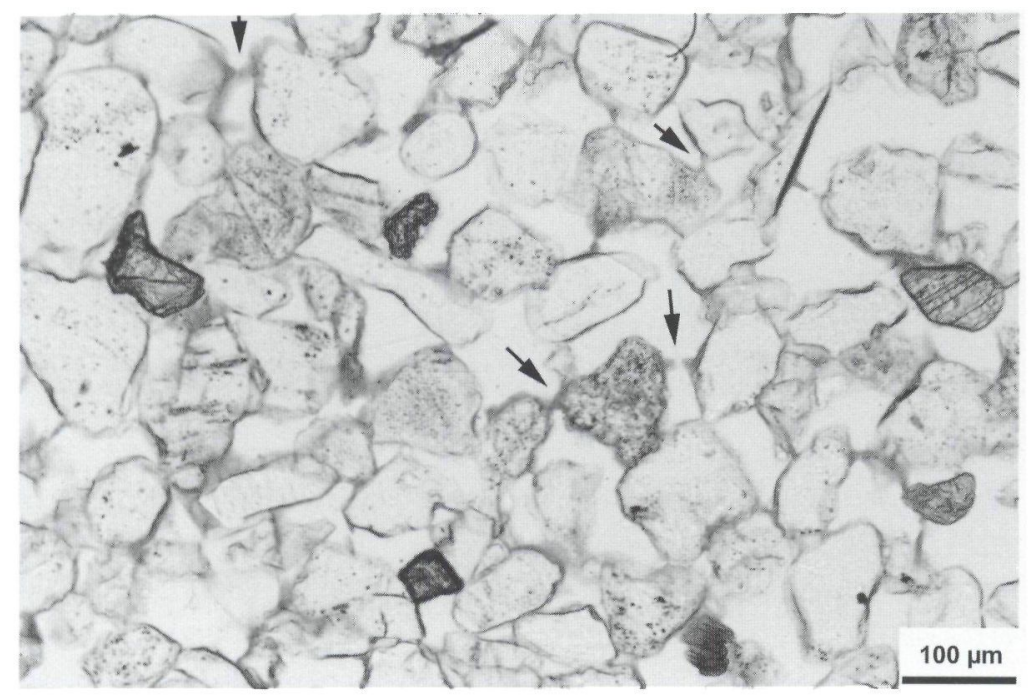

a.

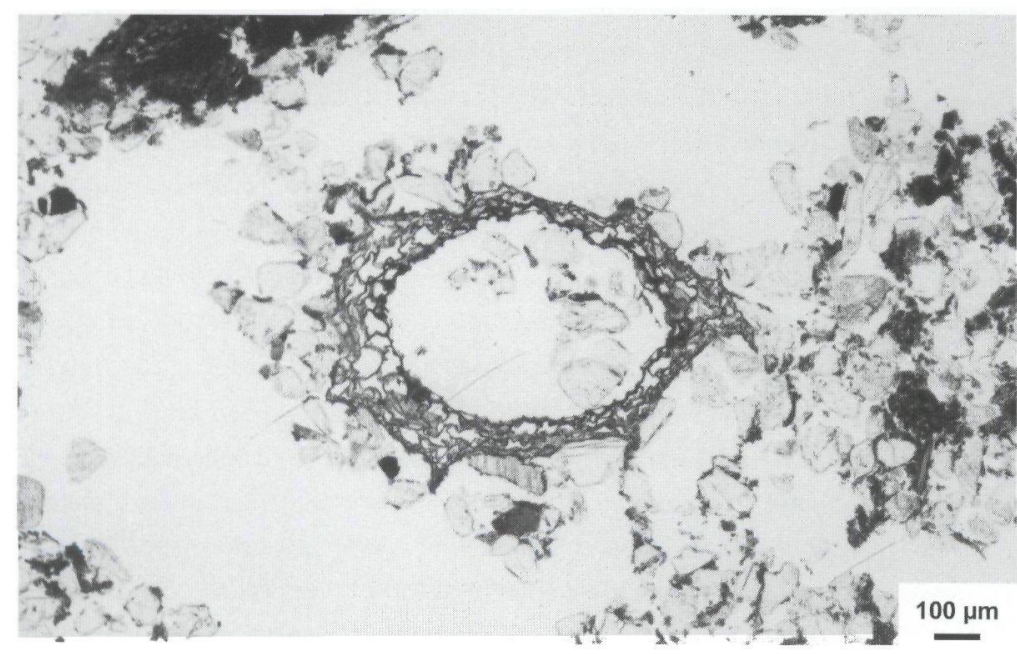

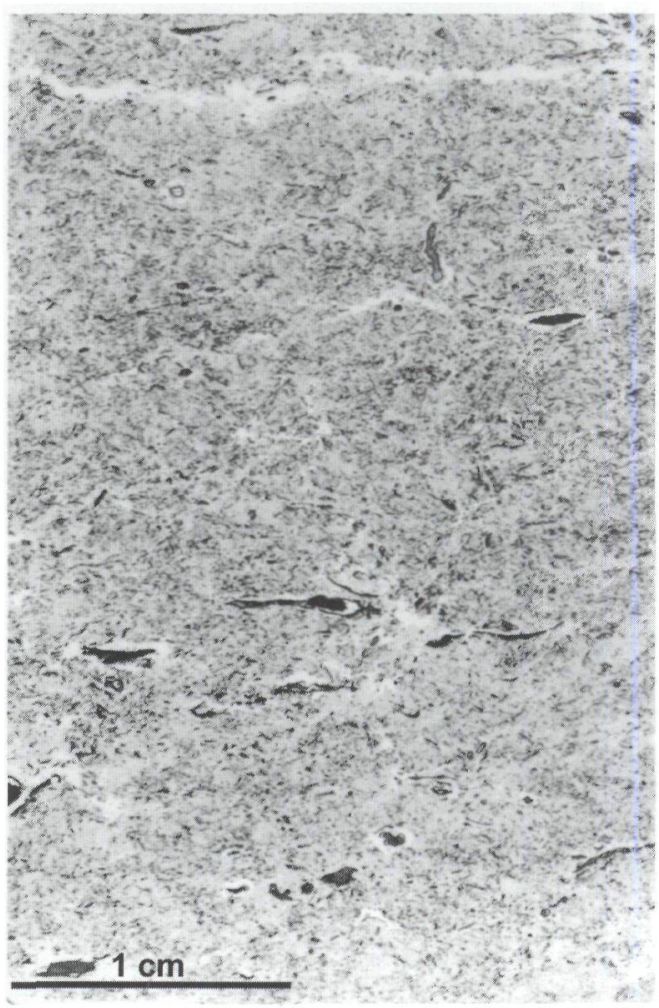

$b$.

Fig. 5. Photomicrographs of profile ADO 42 (photos: P. Kühn); a. Photomicrograph of the Go horizon at $238 \mathrm{~cm}$, plane polarized light. Black arrows point at concave yellowbrown clay bridges (gefuric b-fabric); b. Thin section of the fAeh1 horizon at $248 \mathrm{~cm}$. Almost horizontal layering of longitudinal organic residues; c. Photomicrograph of the fAeh1 horizon at $250 \mathrm{~cm}$, plane polarized light. Perpendicular section of a root in the centre of the photo. The root hardly shows deformation or decomposition effects. 
Interpretation

Distinct clay illuviation features can not be formed under near groundwater conditions. Therefore, oriented clay-hems around minerals and concave clay bridges in the rGo horizon are formed after the groundwater table has dropped. The sharp boundary between the fAeh1 and rGo horizon is marked by a high amount of coarse grains in the rGo horizon. We assume that prior to the main aeolian activity moderate aeolian input led to a layered sand accumulation in the upper part of the fAeh horizons. The characteristic horizontal layering of longitudinal plant tissues alternating with banded sand layers can be interpreted as synsedimentary soil formation of the fAeh horizons. 0therwise the layering should have been homogenised by bioturbation. In the fAeh horizons, the main processes of soil formation were enrichment of organic matter and to a minor degree its humification. Weak bleaching features of Biotite imply a weak silicate weathering. With increasing aeolian activity the amount of sand and coarser grains increases. Therefore, a rapid change of the palaeoenvironmental site conditions can be inferred from the sharp boundary of the fAeh1 to the overlying $\mathrm{rGo}$ horizon. The boundary between the fAeh2 and the underlying frGr horizon is sharp as well. The lamination of the frGr horizon indicates low bioturbation due to groundwater influence.

\section{Geochronology}

\section{Radiocarbon dating}

All samples were taken from the fH horizon in AD0 39 (Table 3, Figs 2, 3). Hv-24639 yielded an age on wood of $10,680 \pm 60 \mathrm{BP}$ $(=12,810-12,700$ cal BP). Poz-3207 and Poz-2212 gave ages on macro remains of $10,030 \pm 200 \mathrm{BP}(11,960-11,250 \mathrm{cal} \mathrm{BP})$ and $10,280 \pm 200 \mathrm{BP}(=12,400-11,700$ cal BP $)$, respectively. The high standard deviation of the latter is caused by a relatively small amount of organic carbon (each with $0.1 \mathrm{mg} \mathrm{C}_{\text {org }}$ ). Nevertheless, both dates are considered to be reliable (pers. comm. T. Goslar, Poznan). Taking the standard deviations into account, the data comprise a time interval from the early Younger Dryas to the early Preboreal (10,740 - 9,830 BP; Björck et al., 1998).

\section{Luminescence dating}

Twelve samples were taken from the aeolian sand of profile ADO 42 (Fig. 2, Table 4). Sample ADO 42-1 from only $18 \mathrm{~cm}$ below the surface was dated to $3.35 \pm 0.23 \mathrm{ka}$. This young age could be a result of post sedimentary mixing with surface material due to bioturbation. Ages of the underlying aeolian sand scatter considerably and do not increase consistently towards the bottom (samples AD0 42-2 to AD0 42-12). Concerning the age errors the sedimentation took place between the Late Pleniglacial and the Early Holocene. To check,
Table 3. Radiocarbon datings from the buried Lateglacial soil of profile ADO 39 ( $C$ = conventional ${ }^{14} \mathrm{C}$ date, $A=A M S{ }^{14} \mathrm{C}$ date). The samples were extracted $120 \mathrm{~cm}$ below the limit of the minerogenic soil. The calibrated ages were calculated using the software Calib Rev4.4.2 (Stuiver \& Reimer, 2005).

\begin{tabular}{|c|c|c|c|c|}
\hline Lab. No. & $\begin{array}{l}{ }^{14} \mathrm{C} \text { age } \\
\text { (years } \mathrm{BP} \text { ) }\end{array}$ & $\begin{array}{l}\text { Age calibrated } \\
\text { (years BP) }\end{array}$ & Material dated & $\begin{array}{l}\delta^{13} \mathrm{C} \\
(0 / 00)\end{array}$ \\
\hline $\mathrm{Hv}-24639(\mathrm{C})$ & $10,680 \pm 60$ & $12,810-12,700$ & $\begin{array}{l}\text { coniferous wood } \\
\text { (probably from } \\
\text { Pinus) }\end{array}$ & -25.9 \\
\hline Poz-2212 (A) & $10,030 \pm 200$ & $11,960-11,250$ & $\begin{array}{l}\text { birch fruits } \\
\text { (probably from } \\
\text { Betula pubescens) }\end{array}$ & -58.2 \\
\hline Poz-3207 (A) & $10,280 \pm 200$ & $12,400-11,700$ & $\begin{array}{l}\text { remains of the } \\
\text { moss Polytrichum } \\
\text { spec. }\end{array}$ & -32.9 \\
\hline
\end{tabular}

whether the scatter in age could be a result of insufficient bleaching of the luminescence signals during short distance transport further experiments have been carried out. A dose recovery' test carried out for sample ADO 42-5, which had been completely bleached before irradiation in the laboratory and OSL measurement, thus simulating ideal conditions at deposition. The test showed, that the relative standard deviations of the equivalent dose distributions (Table 4) for most samples are well within the range of $6 \%$ as measured for the test sample. Furthermore, the detailed investigation of the palaeodose distribution of the sample with the highest equivalent dose value (ADO 42-4) gave no evidence for a significant population of grains which had not been completely bleached during transport and deposition, and therefore would cause an overestimation of the palaeodose and hence the age (Hilgers, 2006). Insufficient bleaching is thus probably not the reason for the high scatter in OSL ages, more likely the problem is caused by dose rate determination. To check the reliability of the NAA results, gamma spectrometry measurements have been carried out for several samples of ADO 42 and ADO 39 (Table 4). In ADO 42-4, AD0 39-1, and ADO $39-3$, dose rates and hence ages differ significantly. In ADO 42-12, the difference is lower and thus the mean of both dose rate values was finally used for age calculation

Because of these difficulties, OSL dates should be interpreted carefully. The aeolian sand was probably deposited within a very short period. The weighted mean of all OSL ages of the samples AD0 42-2 to AD0 42-12 is $12.36 \pm 0.84 \mathrm{ka}$. This date coincides well with the Younger Dryas period $(11,500-12,650 \mathrm{cal}$ BP, Björck et al, 1998; 11,590 - 12,680 cal BP, Litt et al., 2001).

Considering only samples ADO 42-12 and AD0 42-2 from the base and the top of the aeolian sand, there is evidence to suggest that the palaeosol was buried during the Younger DryasPreboreal transition. OSL ages of $11.0 \pm 0.9 \mathrm{ka}$ and $10.9 \pm 0.8 \mathrm{ka}$ 
Table 4. Parameters and results of the dose rate calculation and palaeodose estimation, and the resulting OSL-ages (analysis: A. Hilgers).

\begin{tabular}{|c|c|c|c|c|c|c|c|c|c|c|}
\hline \multirow[t]{2}{*}{ Lab. code } & \multirow[t]{2}{*}{ Sample } & \multirow{2}{*}{$\begin{array}{l}\mathrm{H}_{2} \mathrm{O}^{1} \\
(\%)\end{array}$} & \multirow{2}{*}{$\begin{array}{l}\text { Depth } \\
(\mathrm{cm})\end{array}$} & \multirow{2}{*}{$\begin{array}{l}\text { Uranium } \\
\text { (ppm) }\end{array}$} & \multirow{2}{*}{$\begin{array}{l}\text { Thorium } \\
\text { (ppm) }\end{array}$} & \multirow{2}{*}{$\begin{array}{l}\text { Potassium } \\
(\%)\end{array}$} & \multirow{2}{*}{$\begin{array}{l}\text { Dose rate } \\
(\mathrm{Gy} / \mathrm{ka})\end{array}$} & \multicolumn{2}{|c|}{ Equivalent dose } & \multirow{2}{*}{$\begin{array}{l}\text { OSL-age } \\
\text { (ka) }\end{array}$} \\
\hline & & & & & & & & (Gy) & rel. s.d. ${ }^{2}$ & \\
\hline L0680 & AD039-1 & $4.7 \pm 0.1$ & 62 & $0.50 \pm 0.06$ & $1.79 \pm 0.09$ & $1.12 \pm 0.06$ & $1.46 \pm 0.09$ & $15.8 \pm 0.8$ & 7 & $10.87 \pm 0.85$ \\
\hline L0681 & AD039-2 & $7.3 \pm 0.1$ & 100 & 0.06 & $3.00 \pm 0.15$ & $1.21 \pm 0.06$ & $1.64 \pm 0.09$ & $17.5 \pm 0.9$ & 5 & $10.70 \pm 0.79$ \\
\hline -L0682 & AD039-3 & $12.8 \pm 3.7$ & 124 & 1.63 & 4.61 & $1.40 \pm 0.07$ & $2.03 \pm 0.11$ & $21.0 \pm 1.1$ & 12 & $>10.3$ \\
\hline -L0683 & D039-4 & $.2 \pm 0.1$ & 147 & $0.88 \pm 0.05$ & $2.65 \pm 0.13$ & $1.28 \pm 0.06$ & $1.70 \pm 0.09$ & $20.3 \pm 1.0$ & 7 & $>11.9$ \\
\hline -L0666 & AD042-1 & $5.2 \pm 1.3$ & 18 & $0.63 \pm 0.05$ & $1.88 \pm 0.09$ & $0.56 \pm 0.03$ & $1.02 \pm 0.05$ & $3.41 \pm 0.17$ & 11 & $3.35 \pm 0.23$ \\
\hline -L0667 & 2 & $4.8 \pm 1.3$ & 38 & \pm 0.05 & $2.63 \pm 0.13$ & $0.97 \pm 0.05$ & $.43 \pm 0.07$ & $15.5 \pm 0.8$ & 10 & \pm 0.78 \\
\hline -L0668 & $\mathrm{AD042-3}$ & 3 & 50 & $=0.05$ & 11 & \pm 0.05 & 0.07 & $18.1 \pm 0.9$ & 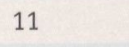 & $13.32 \pm 0.97$ \\
\hline C-L0669 & 4 & $7 \pm 0.2$ & 72 & $=0.06$ & 13 & \pm 0.05 & \pm 0.07 & 1.0 & 7 & $9 \pm 1.07$ \\
\hline L0670 & $042-5$ & $3.8 \pm 0.1$ & 95 & $0.53 \pm 0.06$ & $1.98 \pm 0.10$ & $1.00 \pm 0.05$ & $1.36 \pm 0.07$ & $17.9 \pm 0.9$ & 6 & $13.20 \pm 0.97$ \\
\hline C-L0671 & D042-6 & $3.9 \pm 0.1$ & 116 & $0.56 \pm 0.06$ & $2.25 \pm 0.11$ & $0.95 \pm 0.05$ & $1.34 \pm 0.07$ & $16.8 \pm 0.8$ & 6 & $12.57 \pm 0.94$ \\
\hline C-L0672 & $\mathrm{AD} 042-7$ & $4.9 \pm 0.1$ & 140 & $0.79 \pm 0.06$ & $2.72 \pm 0.14$ & $1.02 \pm 0.05$ & $1.48 \pm 0.07$ & $18.2 \pm 0.9$ & 6 & $12.31 \pm 0.88$ \\
\hline C-L0673 & $\mathrm{AD} 042-8$ & $3.8 \pm 0.2$ & 157 & $0.46 \pm 0.05$ & $1.67 \pm 0.08$ & $1.01 \pm 0.05$ & $1.32 \pm 0.07$ & $16.2 \pm 0.8$ & 6 & $12.31 \pm 0.91$ \\
\hline C-L0674 & $\mathrm{AD} 042-9$ & $4.3 \pm 0.2$ & 181 & $0.40 \pm 0.04$ & $1.68 \pm 0.08$ & $0.95 \pm 0.05$ & $1.24 \pm 0.07$ & $16.3 \pm 0.8$ & 6 & $13.11 \pm 0.99$ \\
\hline C-L0675 & $A D 042-10$ & $3.5 \pm 0.2$ & 200 & $0.38 \pm 0.06$ & $1.71 \pm 0.09$ & $0.92 \pm 0.05$ & $1.21 \pm 0.07$ & $16.3 \pm 0.8$ & 6 & $13.45 \pm 1.05$ \\
\hline C-L0676 & AD042-11 & $3.4 \pm 0.2$ & 218 & $0.37 \pm 0.06$ & $1.29 \pm 0.06$ & $0.94 \pm 0.05$ & $1.20 \pm 0.07$ & $14.9 \pm 0.7$ & 6 & $12.50 \pm 0.98$ \\
\hline C-L0677 & $\mathrm{AD} 042-12$ & $4.1 \pm 0.2$ & 238 & $0.64 \pm 0.05$ & $2.79 \pm 0.14$ & $1.05 \pm 0.05$ & $1.46 \pm 0.07$ & $16.4 \pm 0.8$ & 6 & $11.27 \pm 0.81$ \\
\hline C-L0678 & $\mathrm{AD} 042-13$ & $11.9 \pm 1.4$ & 255 & $1.63 \pm 0.08$ & $5.87 \pm 0.29$ & $1.06 \pm 0.05$ & $1.79 \pm 0.09$ & $19.5 \pm 1.0$ & 5 & $>10.9$ \\
\hline C-L0679 & $\mathrm{AD} 042-14$ & $1.9 \pm 0.3$ & 280 & $0.64 \pm 0.05$ & $1.98 \pm 0.10$ & $0.98 \pm 0.05$ & $1.32 \pm 0.07$ & $17.2 \pm 0.9$ & 6 & $>13.0$ \\
\hline
\end{tabular}

1 Actual water content at the time of sampling in October 2000.

2 Relative standard deviation in $\%$ of the weighted mean.

are similar to the OSL dates $10.9 \pm 0.9$ and $10.7 \pm 0.8 \mathrm{ka}$ obtained for the aeolian sand of profile ADO 39 (samples ADO 39-1, AD0 39-2; Figs 2, 3). This similarity could indicate an aeolian phase of widespread extent. But taking the OSL age for sample AD0 39-1 of 12.6 $\pm 0.8 \mathrm{ka}$ into account, which is based on the gamma spectrometry results for dose rate calculation, a covering of the palaeosol during the Younger Dryas seems similarly possible.

The interpretation of the OSL ages from the glaciolacustrine sands below the buried soils (samples AD0 42-13, AD0 42-14, ADO 39-3, ADO 39-4) is difficult as well, predominantly caused by difficulties in dose rate estimation. Because there are two problems here, which cannot be solved satisfactory, the ages should be regarded as minimum ages. One problem are considerable changes in the water content of the sediment. The water content in the pore volume has to be considered for dose rate calculation, because radiation attenuation is enhanced with rising moisture content in the sediment. The four samples discussed here originate from frGr horizons (Figs 2, 3, Table 4). Higher water contents then the actual measured have to be assumed, especially for the time span after the Holocene transgression of the Baltic Sea (Lampe, 2005) and before drainage improvements and groundwater conveying caused a drop of the groundwater level in the last century. Therefore, dose rate values and OSL dates (Table 4) have been calculated assuming a water content of up to $30 \%$ for at least 6,000 years. Further difficulties are radioactive disequilibria in the uranium decay series. The occurrence of an uranium disequilibrium, caused by the geochemical mobility of uranium and its daughter isotopes, is a well-known problem in waterlogged sediments. In contrast, it is rather unlikely in aeolian deposits (Krbetschek et al., 1994). Disequilibria in the $U$ decay chain occurring in connection with the sedimentation in lacustrine basins often result in uranium excess (Krbetschek et al., 1994). As only the concentration of the parent nuclide of the ${ }^{238} \mathrm{U}$ decay chain is determined by NAA, which was predominantly applied in this study to measure the radionuclide concentration in the sediments, the presence of a disequilibrium could not be investigated. An uranium excess would cause an overestimation of the U content by NAA thus result in too young ages. Therefore, as long as the glaciolacustrine sediments are not checked for radioactive disequilibria in detail, the OSL ages are just minimum age estimates. First analyses using gamma-spectrometry to verify the NAA results illustrate the difficulties in radionuclide determination (Table 4). Based on the knowledge of the regional landscape history, the glaciolacustrine sands were deposited presumably considerable time before the onset of the Younger Dryas (glaciolacustrine sedimentation: ca. 14,000 $13,000 \mathrm{BP}=>15,200 \mathrm{cal}$ BP; Kaiser, 2001).

Recapitulating, the OSL dating at both sites is problematically. Especially the determination of the dose rate suffers from various unpredictability. Thus, the OSL data just produce a rough framework but cannot resolve the chronostratigraphy with satisfying accuracy. 


\section{Botany}

\section{Dendrology}

In total 24 samples of large wooden remains originating from ADO 1, ADO 31, and ADO 39 were analysed (det. by H. Süß, Potsdam). Four samples could not be identified. The samples from ADO 1 and ADO 39 have been collected from the plans. They were part of the $\mathrm{fH}$ horizons bordering immediately to the aeolian sands. The wood was rotten and infiltrated by fungal hyphae. The trunks were ovally deformed by the pressure of covering sands.

In $\mathrm{ADO} 39$, roots, trunks, stumps, and branches of different tree species were identified ( $8 \times$ Betula, $3 \times$ conifer - probably Pinus, $1 \times$ Pinus; Fig. 3). An incompletely excavated trunk of Betula was $290 \mathrm{~cm}$ long and $12 \mathrm{~cm}$ thick.

In AD0 1, besides smaller objects ( $4 \times$ Pinus, $1 \times$ conifer probably Pinus, $1 \times$ Populus; Fig. 3 ), an incompletely excavated trunk of Pinus (240 cm long, $22 \times 14 \mathrm{~cm}$ thick) was discovered.
At AD0 31 two vertical roots of Alnus were found in the buried soil. Based on the low depth of the buried soil and the postglacial re-immigration history of Alnus in this area (Kaffke \& Kaiser, 2002), the roots certainly originate from a Holocene stand of Alnus at this site (secondary position).

\section{Pollen analysis}

Pollen samples from the surface of the buried soil were taken at four sites ( $\operatorname{ADO} 1, \operatorname{ADO} 7, \operatorname{ADO} 31, \operatorname{AD0} 39 ;$ Table 5). The samples thus represent the vegetation towards the end of the formation of the soil. In ADO 39 additionally one sample (ADO 39-3) was taken from the central part of the only $2 \mathrm{~cm}$ thick $\mathrm{fH}$ horizon. Pollen sums are low $(n=86-181)$ because of the very low pollen concentration. Pollen is well preserved in ADO 31-5, AD0 39-2, and AD0 39-3, markedly corroded in AD0 1-9, and strongly corroded in AD0 7-3.

Pinus pollen dominates all samples except for AD0 7-3. Betula pollen occurs in accordingly low percentages. No other tree

Table 5. Results of pollen analysis (analysis: M. Theuerkauf).

\begin{tabular}{|c|c|c|c|c|c|}
\hline \multirow{3}{*}{ Pollen types } & ADO 39-2 & AD0 39-3 & ADO 1-9 & ADO 7-3 & ADO 31-5 \\
\hline & $120-120.5 \mathrm{~cm}$ & $121-121.5 \mathrm{~cm}$ & $195-196 \mathrm{~cm}$ & $205-206 \mathrm{~cm}$ & $76-77 \mathrm{~cm}$ \\
\hline & & & $(\%)$ & & \\
\hline \multicolumn{6}{|l|}{$\mathrm{AP}$} \\
\hline Pinus total & 85.0 & 84.9 & 74.0 & 45.7 & 89.7 \\
\hline Betula total & 14.0 & 10.5 & 25.2 & 53.7 & 9.3 \\
\hline \multicolumn{6}{|l|}{ NAP-upland } \\
\hline Artemisia & 0.9 & 0.0 & 0.8 & 0.0 & 0.0 \\
\hline Chenopodiaceae & 0.0 & 2.3 & 0.0 & 0.0 & 0.0 \\
\hline Ranunculus acris type & 0.0 & 0.0 & 0.0 & 0.0 & 1.0 \\
\hline Rumex acetosella type & 0.0 & 1.2 & 0.0 & 0.0 & 0.0 \\
\hline Anthemis type & 0.0 & 1.2 & 0.0 & 0.0 & 0.0 \\
\hline Circaea & 0.0 & 0.0 & 0.0 & 0.6 & 0.0 \\
\hline Sum AP & 99.1 & 95.3 & 99.2 & 99.4 & 99.0 \\
\hline Sum NAP-upland & 0.9 & 4.7 & 0.8 & 0.6 & 1.1 \\
\hline Pollensum [n] & 107 & 86 & 123 & 181 & 97 \\
\hline
\end{tabular}

\section{NAP divers, Types}

\begin{tabular}{|c|c|c|c|c|c|}
\hline Poaceae & 1.9 & 0.0 & 1.6 & 0.6 & 3.1 \\
\hline cf. Poaceae & 0.0 & 1.2 & 0.0 & 0.0 & 0.0 \\
\hline Cyperaceae & 4.7 & 0.0 & 12.2 & 0.6 & 15.5 \\
\hline Caryophyllaceae undiff. & 4.7 & 0.0 & 0.0 & 0.6 & 0.0 \\
\hline Salix & 0.0 & 1.2 & 0.8 & 0.6 & 0.0 \\
\hline Polypodiales monolet incomplet & 98.1 & 183.7 & 0.8 & 131.9 & 0.0 \\
\hline Sphagnum & 0.9 & 0.0 & 2.4 & 0.6 & 1.0 \\
\hline Microdalyellia spec. (Type 353) & 0.0 & 0.0 & 0.0 & 0.0 & 1.0 \\
\hline Filinia spec. & 0.0 & 1.2 & 0.0 & 0.0 & 0.0 \\
\hline Spirogyra spec. (Type 315) & 3.7 & 1.2 & 1.6 & 0.0 & 4.1 \\
\hline Coniferious wood & 15.9 & 280.2 & 0.0 & 0.0 & 0.0 \\
\hline Gelasinospora spores (Type 1) & 8.4 & 12.8 & 1.6 & 0.6 & 0.0 \\
\hline Indet. & 0.9 & 0.0 & 8.1 & 16.6 & 0.0 \\
\hline Exotic spores & 143.9 & 157.0 & 179.7 & 62.6 & 107.2 \\
\hline
\end{tabular}


pollen was found. Pollen from upland herbs (NAP-upland) are rare $(<1 \%)$, except for AD0 39-3. Sample sites were thus probably densely forested, mostly by Pinus sylvestris. Betula (probably tree birches Betula pubescens/pendula) played only a minor role. More open forests might be assumed at an earlier stage because of higher percentages of NAP-upland pollen (Chenopodiaceae, Rumex acetosella type, and Anthemis type) in ADO 39-3. However, the absence of other typical indicators of open forests (e.g. Artemisia, Juniperus) does not support this assumption.

On the other hand, macrofossil analysis (see further) indicates that the buried soils developed partly under open forest vegetation. Pollen samples from relatively open sites reflect vegetation composition on a larger scale with a diameter of 100 - $1000 \mathrm{~m}$ (e.g. Jacobson \& Bradshaw, 1981). As also indicated in ADO 40 (see below), Pinus probably dominated in such a larger area. In pollen samples AD0 31-5, AD0 39-2, and AD0 39-3 Pinus dominates while only macrofossils of treebirches were found. The vegetation might thus be interpreted as small stands of scattered tree birches in a forest dominated by Pinus. The dominance of Pinus and low NAP-upland percentages points to pollen spectra dating into the late Allerød or the Allerød-Younger Dryas transition as known from other Lateglacial sequences in the region (e.g. de Klerk, 2002).

Cyperaceae pollen was found in high percentages in AD0 1-9, ADO 31-5, and ADO 39-2, but hardly occurs in AD0 7-3 and AD0 39-3. Poaceae pollen is similarly distributed, but less abundant. Polypodiales monolet incomplet spores have very high percentages in AD0 7-3, ADO 39-2, and AD0 39-3 (98.1 $183.7 \%$ ), but hardly occur in ADO 1-9 and ADO 31-5 (0.8\% and $0.0 \%$ ). At $\mathrm{ADO} 1$ and $\mathrm{ADO} 31$ vegetation was probably rich in grasses and sedges, at ADO 7 and ADO 39 rich in ferns. At a later stage grasses and sedges became more important at AD0 39. Sphagnum spores were most abundant in AD0 1-9 (2.4\%). 0nly single spores occurred in ADO 39-2, ADO 7-3, and AD0 31-5. No Sphagnum spores were found in ADO 39-3. Here however, the occurrence of Sphagnum is shown by macrofossil analysis (see below). In all samples except for AD0 7-3 nonpollen palynomorphs that indicate open water were detected. Spores of Spirogyra spec. occurred in four samples, Microdalyellia spec. and Filinia spec. each in one sample (Table 5). AD0 7 was probably much drier than the other sites, explaining the bad preservation of pollen and macrofossils.

Additional palynological data are available from profiles ADO 40 and AD0 39: samples of pollen diagram AD0 40 were already extracted in 1999 by coring (Kaiser, 2001). Thus small deviations in depth and thickness of the buried sediments are to consider. Samples were taken from peat and gyttja in 223 $263 \mathrm{~cm}$ below the surface (Fig. 6). The progression of tree pollen types resembles that of other Lateglacial sequences in the region (e.g. de Klerk, 2002). The diagram comprises Lateglacial vegetation zones from the oldest Dryas to the Younger Dryas. The buried soil surface is represented by a peat dating into the late Allerød.

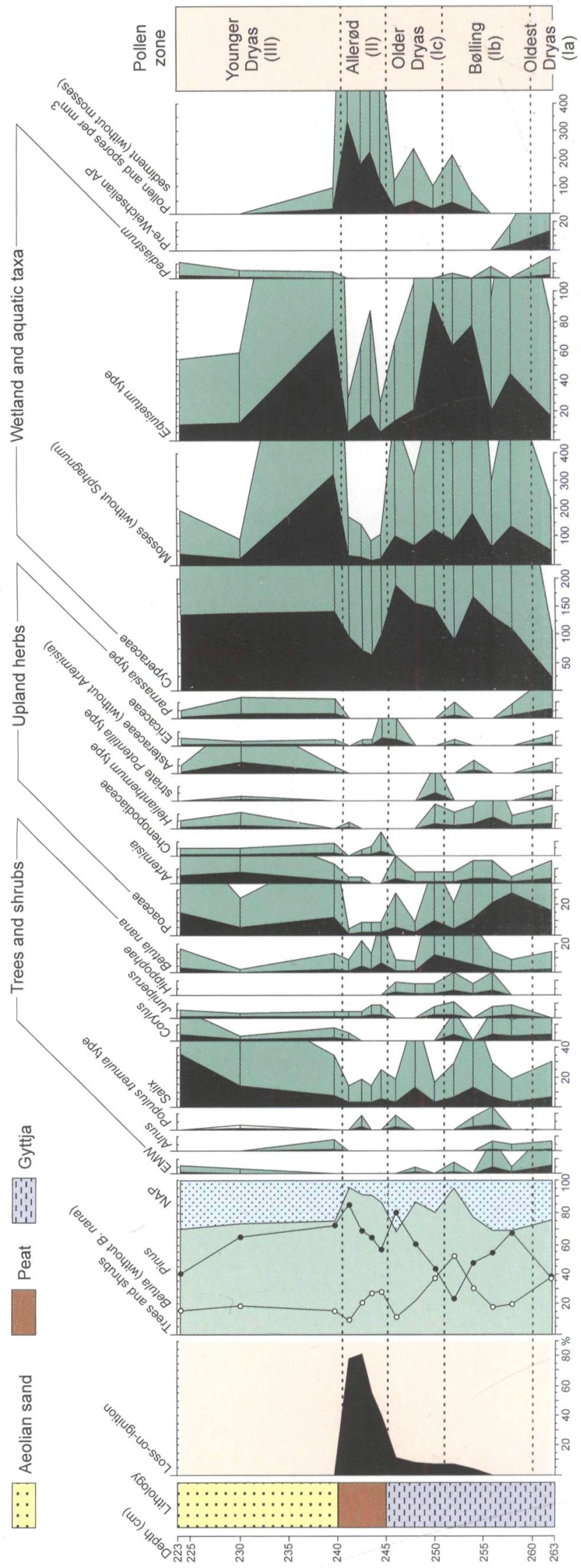

Fig. 6: Pollen diagram ADO 40 representing selected taxa based on the upland pollen sum with AP and shrubs (analysis: W. Janke). Exaggeration of microfossil curves 5x. (Pollen zones after Firbas, 1949). 
Pollen diagram AD0 39-S was taken in the south of trench AD0 39 (Figs 3, 7). It represents a (Relic-) Gleyic Podzol near the present surface, covered by a peat layer and mor. Pollen analysis was carried out to (post) date the sandy aeolian substrate of the soil. Pollen analysis in soils faces major problems (e.g. Tipping et al., 1999). However, the diagram reflects typical features of the regional pollen stratigraphy, e.g. the first Ulmus-decline marking the end of the Atlantic period, and the beginning of continuous presence of Fagus and Carpinus. Despite a length of only $60 \mathrm{~cm}$, the diagram comprises several Holocene pollen zones described from the much longer peat profile ADP of the Altdarss area (Kaffke \& Kaiser, 2002) as well as from other profiles of the surroundings (e.g. Fukarek, 1961; Kaiser et al, 2000; Lampe \& Janke, 2004). Pollen samples from the lower sandy part are attributed to the Atlantic. The topping peat and mor date into the Subboreal and Subatlantic, respectively.

\section{Macrofossil analysis}

Samples AD0 1 and AD0 39 were dominated by Sphagnum sect. Acutifolia leaves and branches, and undeterminable Sphagnum remains (Table 6). Most respective taxa indicate wet, nutrient poor, and acidic conditions (Frahm \& Frey, 1992). Seeds of Empetrum nigrum were found in both samples, Polytrichum strictum only in AD0 1. Empetrum nigrum indicates acidic and nutrient poor conditions (Oberdorfer, 1994), Polytrichum strictum wet and acidic conditions with a vegetation rich in Sphagnum (Frahm \& Frey, 1992).

At AD0 39 pieces of wood were identified as Betula. Fruits of Betula (mainly Betula pubescens/pendula) indicate the presence of Betula trees. Charred seeds of Empetrum nigrum indicate fire at ADO 1 and ADO 39.

Sample AD0 31 is dominated by woody macrofossils. Betula bud scales were recorded. Betula (trees or dwarf shrubs) was probably growing at the site during the genesis of the buried soil. Diaspores of Carex lasiocarpa and Menyanthes trifoliata indicate wet, occasionally flooded, and moderately nutrient rich conditions (Oberdorfer, 1994) with a higher $\mathrm{pH}$ value than it is indicated at ADO 39 and ADO 1. They also are light demanding plants (Ellenberg, 1992), allowing only scattered trees or dwarf shrubs. Diaspores of Potamogeton species indicate the presence of long time flooded areas, e.g. small ponds (Oberdorfer, 1994).

Sample ADO 7 is dominated by woody macrofossils partly from Betula. The high amount of undeterminable tissue indicates a high degree of decomposition. Reconstruction of the vegetation during the genesis of the buried soil is fragmented possible only. However, the high degree of decomposition indicates drier conditions at ADO 7 compared to the other sites.

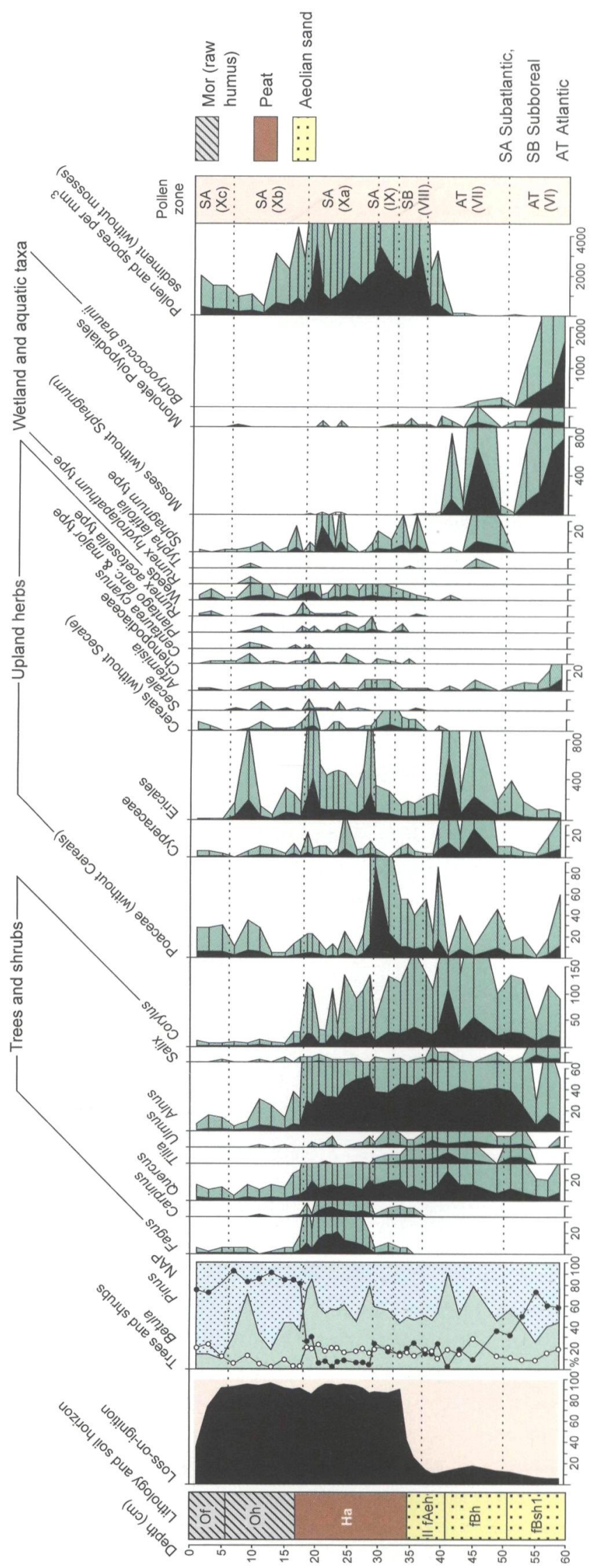

Fig. 7. Pollen diagram ADO 39-S representing selected taxa based on the upland pollen sum with AP and shrubs (analysis: W. Janke). Exaggeration of microfossil curves 5x. (Pollen zones after Firbas, 1949). 


\section{Palaeoenvironmental synthesis}

First of all it has to be clarified whether the palaeosols belong to an isochronous surface. All 42 investigated profiles show an uniform succession of basal glaciolacustrine sand, intermediate palaeosol, and aeolian sand on top. The aeolian cover is memberless, except for thin oM horizons indicating soil erosion at the beginning of the aeolian phase. Furthermore, Holocene

Table 6. Results of macrofossil analysis; $a$. Counting of diaspores and bud scales; $b$. Share of tissue types in the sample volume (estimation grades: $+=>1 \%, 1 a=>1 \%, 1 b=1-3 \%, 2=4-9 \%, 3=10-24 \%, 4=25-49 \%, 5=50-79,6=80-100 \%$; analysis: A. Barthelmes).

\begin{tabular}{|c|c|c|c|c|}
\hline \multirow[t]{3}{*}{ Macrofossils: Counting } & AD0 39 & ADO 1 & AD0 31 & ADO 7 \\
\hline & $120-121 \mathrm{~cm}$ & $195-196 \mathrm{~cm}$ & $76-77 \mathrm{~cm}$ & $205-206 \mathrm{~cm}$ \\
\hline & \multicolumn{4}{|c|}{ (number) } \\
\hline Betula cf. nana fruit & 2 & - & - & - \\
\hline Betula pubescens/pendula fruit & 31 & - & - & - \\
\hline Juncus spec. seed & 1 & - & - & - \\
\hline Sphagnum fuscum leaf of stem & 2 & - & - & - \\
\hline Empetrum nigrum seed & 9 & - & - & - \\
\hline Empetrum nigrum part of a seed & 11 & 3 & - & - \\
\hline Empetrum nigrum anther & - & 1 & - & - \\
\hline Empetrum nigrum seed (burnt) & - & 8 & - & - \\
\hline bud scale indet. & - & 5 & 2 & - \\
\hline Salix spec. bud scale & - & 2 & 2 & - \\
\hline Betula spec. bud scale & - & - & 9 & - \\
\hline Carex lasiocarpa utriculus & - & - & 11 & - \\
\hline Menyanthes trifoilata seed & - & - & 11 & - \\
\hline Potamogeton spec. endocarp & - & - & 2 & - \\
\hline Carex tricarpellate seed & - & - & 4 & - \\
\hline
\end{tabular}
a.

\begin{tabular}{|c|c|c|c|c|}
\hline \multirow[t]{3}{*}{ Macrofossils: Share of tissue types } & AD0 39 & ADO 1 & ADO 31 & ADO 7 \\
\hline & $120-121 \mathrm{~cm}$ & $195-196 \mathrm{~cm}$ & $76-77 \mathrm{~cm}$ & $205-206 \mathrm{~cm}$ \\
\hline & \multicolumn{4}{|c|}{ (estimation grade) } \\
\hline Polytrichum strictum & 3 & - & - & - \\
\hline Sphagnum spec. leafs & 3 & - & - & - \\
\hline Sphagnum spec. stem & $1 \mathrm{a}$ & 2 & - & - \\
\hline Sphagnum sect. Acutifolia leafs & 4 & 4 & - & - \\
\hline Betula spec. wood & $1 \mathrm{~b}$ & $1 b$ & - & - \\
\hline Burnt material & 2 & 2 & - & 2 \\
\hline Betula spec. periderm & $1 b$ & 2 & $1 b$ & 2 \\
\hline Wood & 2 & 2 & 2 & 2 \\
\hline Wooden fibres & $1 \mathrm{~b}$ & 2 & - & 2 \\
\hline Wooden radicels & $1 b$ & 3 & 5 & 4 \\
\hline Radicels of herbaceous plants & 2 & 2 & 2 & 2 \\
\hline Chitinous animal remains & $1 \mathrm{a}$ & $1 \mathrm{a}$ & $1 \mathrm{~b}$ & $1 \mathrm{~b}$ \\
\hline Amorphously organic material & $1 b$ & $1 \mathrm{~b}$ & $1 a$ & 3 \\
\hline Tissue indet. & 2 & 3 & 3 & 3 \\
\hline Brown moss indet. & - & $1 b$ & 2 & - \\
\hline Homalothecium nitens & - & $1 \mathrm{~b}$ & - & - \\
\hline Epidermis of leafs of Cyperaceae & - & $1 a$ & - & - \\
\hline Stems of mosses & - & $1 b$ & - & - \\
\hline Pinus spec. periderm of roots & - & $1 \mathrm{a}$ & - & - \\
\hline Calliergonella cuspidata & - & - & $1 b$ & - \\
\hline Periderm indet. & - & - & $1 a$ & - \\
\hline
\end{tabular}
b. 


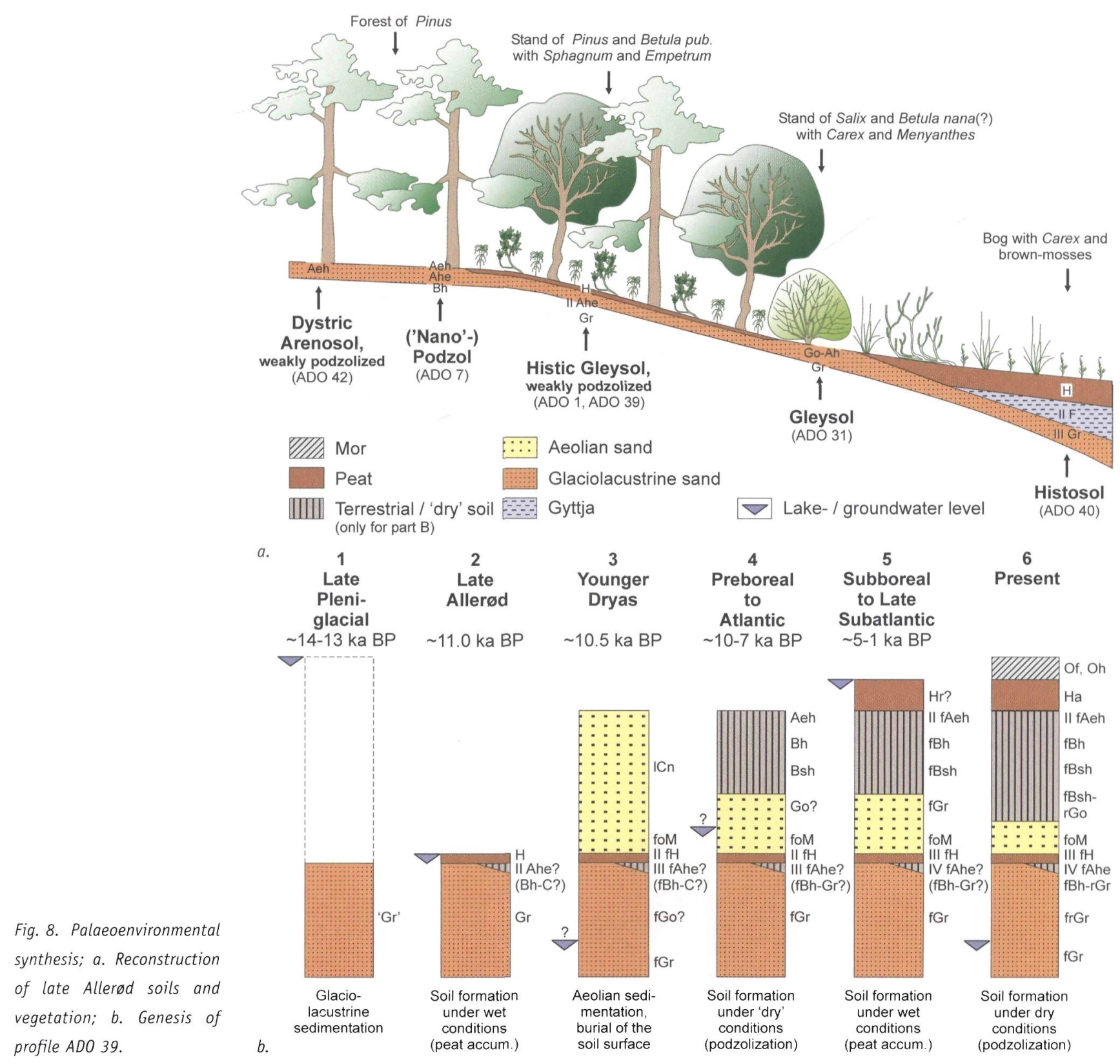

peats developed in some profiles that cover the aeolian sands. Direct or indirect dating of the buried soil was possible in all profiles, but the dates differ. Taking the standard deviations into account, the radiocarbon ages from profile AD0 39 comprise a time interval of early Younger Dryas to early Preboreal (10,740 - 9,830 BP; Björck et al., 1998). The upper part of the peat in profile AD0 40 was dated palynologically into the late Allerød. The high values of Pinus in profiles ADO 1, ADO 7, ADO 31, and ADO 39 also indicate a late Allerød age. The OSL ages of profiles ADO 39 and ADO 42 suggest that the palaeosols were covered by aeolian sands within the time interval Younger Dryas to Younger Dryas-Preboreal transition. The palynological results dated the buried soil surface into the late Allerød. This requires a rejuvenation of the radiocarbon dates, which possibly was caused by contamination with younger carbon (Wohlfarth et al., 1998; Turney et al., 2000).

Based on the palynological dating, the rejuvenation could amount to 500 - 1000 years. To sum up, it seems given, that the palaeosols and the contact soil-aeolian sand, respectively, form an isochronous surface. The buried soil surface dates into the late Allerød, while the aeolian sands were deposited during the Younger Dryas. Thus, previous information given on a slight younger age of the palaeosol cover (Kaiser, 2004; Terberger et al., 2004) must be corrected.

The buried soils as well as the vegetation reconstructed can be arranged in a catena and a transect, respectively (Fig. 8a). It covers a range of $1.6 \mathrm{~m}$ in height except for $\mathrm{AD0} 7$ (2.2 $3.8 \mathrm{~m}$ a.s.l.; Fig. 2). ADO 42 is situated at the highest position. The fAhe horizons display soil formation under the weak influence of drifting sands. This buried Arenosol is the only soil profile which reflects unstable site conditions during soil formation. At site $\mathrm{ADO} 7$, despite its lowermost position in the 
present-day transect, soil type ('Nano'-Podzol) and the high degree of decomposition of organic matter indicate that the soil was formed under relatively dry conditions. The profile was most probably displaced vertically after soil formation (possibly by dead-ice melting?).

Pedological and botanical results indicate the prevalence of moist, partly wet site conditions along the catena, except for ADO 7 and AD0 42. As shown by the dendrological results, sites AD0 1 and ADO 39 (Histic Gleysols) were forested by Pinus and Betula. Macrofossils of the ground vegetation, dominated by Sphagnum sect. Acutifolia and Empetrum nigrum, reflect wet, acidic, and nutrient poor conditions. The palynological results show, that the forests surrounding the sampling sites were dominated by Pinus. Betula played a role in the local vegetation on wet sites. Macrofossils of ADO 31 (Gleysol) indicate a wet, occasionally flooded site moderately rich in nutrients. This site was dominated by sedges and scattered stands of Betula. At ADO 40, the lowermost site, mire vegetation was reconstructed. It was dominated by brown-mosses and sedges, and probably surrounded by a belt of Salix and Betula (compare Bos et al., 2006).

A reconstruction of the soil formation and local landscape development through time is summarised with profile AD0 39 as an example (Fig. 8b). The initial stage was a large icedammed lake that was terminated during the Late Pleniglacial by a marked drop in the lake level. A high groundwater level during the Lateglacial resulted in the formation of peat. In the Younger Dryas, accompanied by a falling groundwater level, the peat surface was covered with aeolian sand. The podzolization of the aeolian sand occurred probably in the time interval from the Preboreal to the Atlantic. A significant rise in the groundwater level during the Subboreal and Subatlantic caused the formation of a peat layer. This groundwater rise was probably triggered by the Late Holocene transgression of the Baltic Sea (Lemke, 1998; Lampe, 2005). Recently, drainage improvements and water conveyance resulted in a falling groundwater level, drier site conditions with renewed podzolization, and the enforced formation of mor. Both regional landscape development and local site genesis of the Altdarss area is summarised in Fig. 9.

\section{Discussion}

The buried soil cover of the Altdarss area comprises a succession from relatively dry via moist to wet palaeosites. Profiles ADO 7 ('Nano'-Podzol) and AD0 42 (weakly podzolized Dystric Arenosol) are similar to the Usselo soil, as described from NW Europe and Poland (Manikowska, 1991; Hoek, 1997; Kasse, 1999; Kaiser \& Clausen, 2005). Consequently, this record and the absence of a distinct silicate weathering (Bv/Bw horizon), attributed to the Finow soil, assign the Altdarss area to the 'province' of the Usselo soil. The overlying aeolian sands can be correlated with the 'Younger Coversand II' of NW Europe (Kasse, 1999; Schirmer, 1999; Koster, 2005).

In the last decade, several new locations with Lateglacial sandy palaeosols were found in NE Germany: close to the Altdarss site, Lateglacial buried palaeosols were also found in the Rostocker Heide and Barther Heide area, situated in the

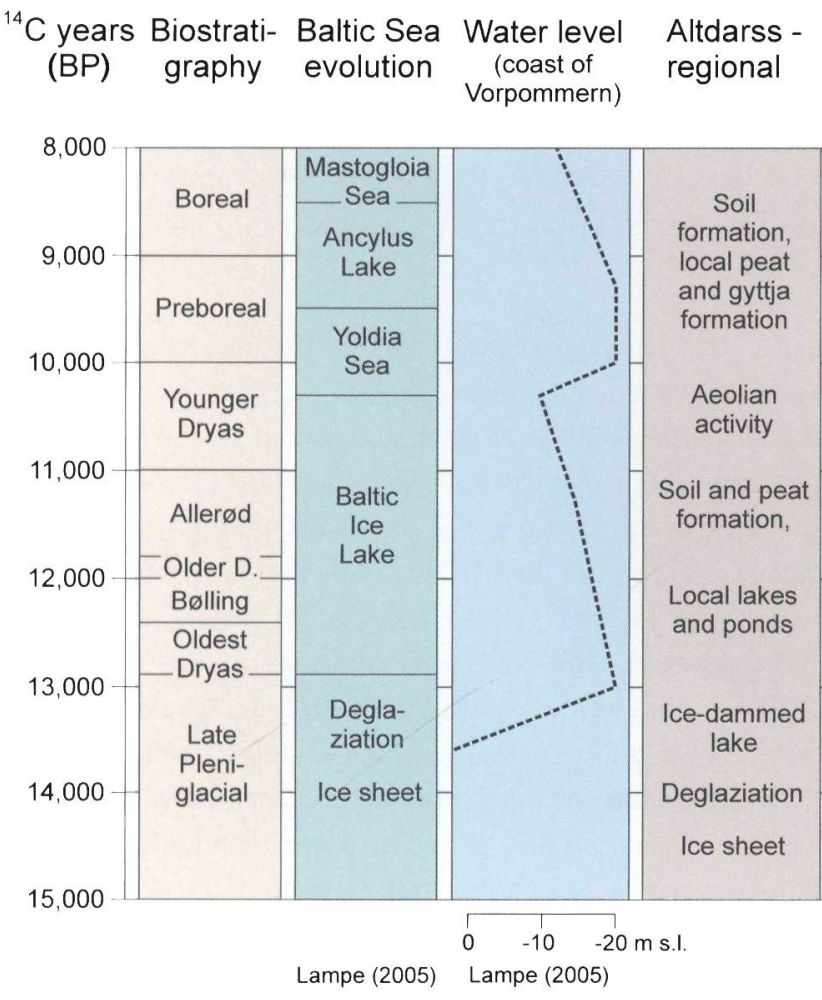

Altdarss - local

Soil formation and sedimentation ADO 7 ADO 39 ADO 40 ADP

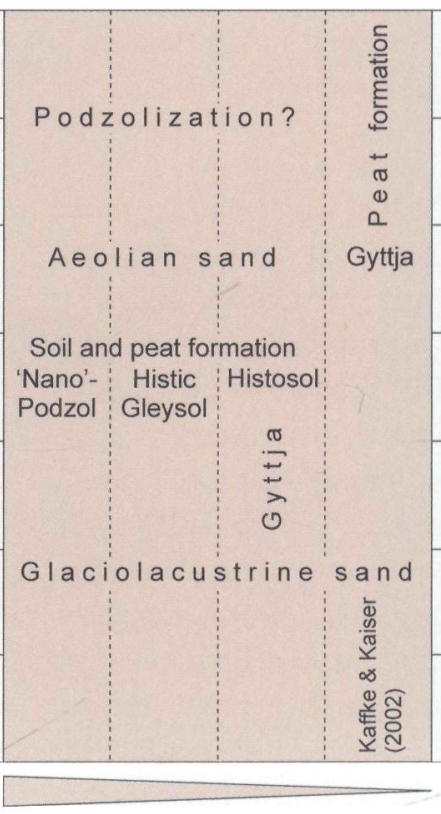

Altitude palaeo-surface
Altdarss - local

Vegetation (upland) ADO 7 ADO 39 ADO $40 \quad A D P$

\begin{tabular}{l|l|l}
\hline$\vdots$ & Hazel-
\end{tabular}
Hazelpine $w$. Birchpine w. Open birch w. with pine

Open pine woodlands with birch

Shrubs

Grasses herbs

Fig. 9. Regional landscape development and local site genesis of the Altdarss area. 
same glaciolacustrine basin. In the adjacent Barther Heide area (Fig. 1) three profiles consisting of basal glaciolacustrine silts and sands, intermediate gyttjas and covering aeolian sands were investigated (Kaiser, 2001). The gyttjas have been dated palynologically to the Bølling to early Younger Dryas period. Thus, both areas show the same geomorphic character during the termination of the Pleistocene.

Another well-known site is situated in the Rostocker Heide area. Since the late 19th century, stratigraphical investigations were repeatedly performed at the so-called 'Heidesandkliff', a cliff exposure of the Baltic Sea (studies summarised in Kaiser, 2001). A layer of lacustrine and telmatic sediments as well as a buried palaeosol (named as Usselo soil; Ludwig, 2002) covered by aeolian sands have been described. Parts of the buried soil cover were dated to the Allerød using pollen and macrofossils. In a peat layer, stumps and trunks of pine were found after extremely high tides of the Baltic Sea (Süß, 1968). A radiocarbon sample of pine was dated at 11,220 $\pm 250 \mathrm{BP}$ and confirmed an Allerød age (Ludwig, 2002).

In the Ueckermünder Heide area, ca. $140 \mathrm{~km}$ further to the southeast, at the Late Palaeolithic Hintersee and Forst Mützelburg sites weakly developed Cambisols of the Finow soil type have been found (thickness of $\mathrm{Bv}$ horizons $7-14 \mathrm{~cm}$; Bogen et al., 2003). The buried soils are developed from glaciolacustrine sands and covered by aeolian sands. According to the artefacts in the palaeosols (Ahrensburgian; usually assigned to the Younger Dryas) and OSL dating (weighted means of the aeolian sands: $12.12 \pm 0.49 \mathrm{ka}, \mathrm{n}=6$, and $12.18 \pm 0.57 \mathrm{ka}, \mathrm{n}=3$ ), a land surface has still existed during the early Younger Dryas (Allerød-Younger Dryas boundary acc. to Björck et al., $1998=12,650 \mathrm{cal} \mathrm{BP}$; acc. to Litt et al., $2001=12,680 \mathrm{cal} \mathrm{BP}$ ). Furthermore, a buried Bt horizon (Luvisol) with a thickness of about $15 \mathrm{~cm}$ was described in the vicinity of the Late Palaeolithic Forst Mützelburg site (Kühn, 2003). The OSL dating of the covering aeolian sand $(9.59 \pm 0.62 \mathrm{ka})$ suggests a Lateglacial age of the buried Bt horizon. Organic components, such as humus, charcoal or wood, are not preserved at these terrestrial sites and thus prevents a comparison with other radiocarbon dated studies.

A further complex of buried palaeosols has been recorded from Wolin Island, NW Poland (Borowka et al., 1986, 1999). Besides Histosols and Gleysols also soils of the Usselo type as well as the Finow type were reported. Pollen analysis and one radiocarbon age $(11,590 \pm 270 \mathrm{BP})$ date the buried soil cover into the Allerød.

This indicates that the border of present occurrences of the Usselo and Finow soil can be placed in between the Altdarss and the Ueckermünder Heide area. A dated occurrence of the Finow soil close to Krakow am See, Mecklenburg Lake District $(10,938 \pm 69 \mathrm{BP}$; Lorenz, 2006) suggests that the Altdarss site has a minimum distance of about $90 \mathrm{~km}$ to the area of Finow soil occurrences.
In NE Germany, the Finow soil (Bv horizons with thicknesses of $15 \mathrm{~cm}$ in maximum) is found within an area of ca. $250 \times 150 \mathrm{~km}$, with Krakow am See being the northernmost site. In depressions the Finow soil laterally corresponds to Gleysols at moist and peats or gyttjas at wet sites. Five radiocarbon ages between $11,800 \pm 140 \mathrm{BP}$ and 10,290 \pm 385 BP date the Finow soil in the period Older Dryas to Younger Dryas-Preboreal transition (Bussemer et al., 1998; Schlaak, 1998; Schirmer, 1999; Lorenz, 2006).

Near Cottbus (Niederlausitz), Lateglacial soils were discovered during archaeological excavations. A pattern of buried soils consisting of ('Nano'-) Podzols, Gleysols, Histosols, and gyttjas have been reported from the lignite open-cast mine 'CottbusNord' (Bittmann \& Pasda, 1999; Pasda, 2002). The soils are buried by aeolian sands as well as by fluvial sands of the Spree River. Eight radiocarbon dates range from $11,000 \pm 100 \mathrm{BP}$ to $9,780 \pm 75$ BP. The majority of the ${ }^{14} \mathrm{C}$-data cluster into the Younger Dryas. Trunks of pine up to a length of $9 \mathrm{~m}$ have been excavated at a wet site (Gleysol) dating between 10,310 \pm $45 \mathrm{BP}$ and 10,148 $\pm 84 \mathrm{BP}$. Pollen analysis indicates, that the trees were rooting into a soil horizon formed during the Allerød (Spurk et al., 1999). However, a precise pedological record including soil analysis was not performed here.

Furthermore, Lateglacial soils underlying a telmaticlacustrine sequence were investigated in the lignite open-cast mine 'Reichwalde', ca. $50 \mathrm{~km}$ south of Cottbus (Friedrich et al., 2001). It is divided into an upper buried soil ('Nano-PodsolBraunerde' $=$ podzolized Cambisol), an intermediate layer of aeolian sand, and a lower buried soil (Arenosol). Both soils have a thickness of ca. $10-15 \mathrm{~cm}$. The lower soil yielded a radiocarbon age of $12,100 \pm 130 \mathrm{BP}$ (Bølling). Some kilometres to the north, a buried podzolized Cambisol was recorded. It was radiocarbon dated to $11,400 \pm 190 \mathrm{BP}$ (Allerød). The authors suggested that during the Lateglacial a multiphase soil formation from Arenosols via Cambisols to ('Nano'-) Podzols took place at both sites. Close to the Reichwalde site, further occurrences of Lateglacial soils underlying dunes were reported from the lignite open-cast mines 'Scheibe' and 'Nochten' $(11,800 \pm 140 \mathrm{BP}$, without designation of a soil type; Mol, 1997).

Finally, records on the Lateglacial to Early Holocene soil development in the surroundings of oligotrophic mires are available from the Berlin region (Brande, 1995; Alaily \& Brande, 2004).

Summarising, the records of Lateglacial buried palaeosols in NE Germany can be dated between Bølling and early Preboreal. Most dates cluster into the Allerød and Younger Dryas. The soils were covered by aeolian sands, deposited mainly during the Younger Dryas.

Lateglacial palaeosols underlying the 'Younger Coversand II' from NW Europe are dated into the same period. In the Netherlands, 23 radiocarbon dates from charcoal in various Usselo soil occurrences comprise a time interval of about 
$1,400{ }^{14} \mathrm{C}$-years $(11,440 \pm 120 \mathrm{BP}$ to $10,365 \pm 200 \mathrm{BP})$ and cluster around 11,000 BP (Hoek, 1997). Records of the Usselo soil from NW Germany were in general assigned to the Allerød (e.g. Roeschmann et al., 1982). However, these records yielded radiocarbon ages between Older Dryas and Younger Dryas (e.g. Kaiser \& Clausen, 2005). Thus, strictly speaking, the buried soils of Usselo and Finow type in Germany represents no Allerød soil but rather a Lateglacial soil.

\section{Conclusions}

In NE Germany, patterns of buried Lateglacial soils have been recorded repeatedly. For the Altdarss area a multidisciplinary analysis was carried out in order to document the features and lateral arrangement of the palaeosols. Here, the buried soil cover (ca. $3.4 \mathrm{~km}^{2}$ ) comprises a catena from relatively dry ('Nano'-Podzol, Arenosol) via moist (Histic Gleysol, Gleysol) to wet conditions (Histosol). Soils of the dry sites are similar to the Usselo soil, as described from NW Europe and Poland. Both the analysis of single pollen samples and a pollen diagram indicate that the palaeosol cover dates into the late Allerød. The radiocarbon dates are 500 to 1,000 years to young, probably due to the contamination with younger carbon. OSL dates suggest that the covering by aeolian sands occurred during the Younger Dryas. Large wooden remains were found in the palaeosols (roots, trunks, stumps, and branches of Pinus and Betula). Pollen and macrofossil analyses enabled the reconstruction of a vegetation pattern typical for the late Allerød. The forests at relatively dry sites were dominated by Pinus, while at wet sites mosses, sedges and stands of Betula occurred.

\section{Acknowledgements}

We are indebted to A. Baumgart Born, and K. Billwitz, Hude, for their generous scientific and financial support of our investigations. We owe the determination of the woods to H. Süß, Potsdam. Permission for working in the National Park 'Vorpommersche Boddenlandschaft' and technical support were kindly provided by K. Bärwald and A. Schlabs, both Born. Special thanks are extended to B. Lintzen, H. Rabe, and P. Wiese, all Greifswald, for laboratory and drawing workings. Finally, we would like to thank H. Bos, Utrecht, R. Dambeck, Frankfurt am Main, and C. Kasse, Amsterdam, for helpful comments on the manuscript as well as to J. Hooker, Bergen, for the improvement of the English.

\section{References}

AG Boden, 1994. Bodenkundliche Kartieranleitung (4th edition). Schweizerbart'sche Verlagsbuchhandlung (Hannover): 392 pp.

Aitken, M.J., 1998. An introduction to optical dating - The dating of Quaternary sediments by the use of photon-stimulated luminescence. Oxford University Press (0xford): $267 \mathrm{pp}$.

Alaily, F. \& Brande, A., 2004. Soil association in the surroundings of oligotrophic mires in the Berlin region. International Peat Journal 12: 21-31.

Billwitz, K., 1997. Überdünte Strandwälle und Dünen und ihr geoökologisches Inventar an der vorpommerschen 0stseeküste. Zeitschrift für Geomorphologie N.F., Supplement 111: 161-173.

Bittmann, F. \& Pasda, C., 1999. Die Entwicklung einer Düne während der letzten 12000 Jahre - Untersuchungsergebnisse von Groß Lieskow (Stadt Cottbus) in der Niederlausitz. Quartär 49/50: 39-54.

Björck, S.M., Walker, J.C., Cwynar, L.C., Johnsen, S., Knudsen, K.-L., Lowe, J.J., Wohlfarth B. \& INTIMATE Members, 1998. An event stratigraphy for the Last Termination in the North Atlantic region based on the Greenland ice-core record: A proposal by the INTIMATE group. Journal of Quaternary Science 13: 283-292.

Bogen, C., Hilgers, A., Kaiser, K., Kühn, P. \& Lidke, G., 2003. Archäologie, Pedologie und Geochronologie spätpaläolithischer Fundplätze in der Ueckermünder Heide (Kr. Uecker-Randow, Mecklenburg-Vorpommern). Archäologisches Korrespondenzblatt 33: 1-20.

Borowka, R.K., Gonera, P., Kostrzewski, A., Nowaczyk, B. \& Zwolinski, Z., 1986. Stratigraphy of eolian deposits in Wolin Island and the surrounding area, North-West Poland. Boreas 15: 301-309.

Borowka, R.K., Belczynska, A. \& Tomkowiak, J., 1999. Cechy morfologiczne i wybrane wlasciwosci chemiczne gleb kopalnych rozwinietych na piaskach eolicznych w okolicach Swietoujscia i Grodna. In: Borowka, R.K., Mlynarczyk, Z. \& Wojciechowski, A. (eds): Ewolucja geosystemow nadmorskich poludniowego Baltyku. Bogucki Wydawnictwo Naukowe (Poznan-Szczecin): 37-42.

Bos, J.A.A., Bohncke, S.J.P. \& Janssen, C.R., 2006. Lake-level fluctuations and small-scale vegetation patterns during the late glacial in The Netherlands. Journal of Paleolimnology 35: 211-238.

Brande, A., 1995. Moorgeschichtliche Untersuchungen im Spandauer Forst (Berlin). Schriftenreihe für Vegetationskunde 27: 249-255.

Bussemer, S., Gärtner, P. \& Schlaak, N., 1998. Stratigraphie, Stoffbestand und Reliefwirksamkeit der Flugsande im brandenburgischen Jungmoränenland. Petermanns Geographische Mitteilungen 142: 115-125.

Czakó Pap, S., 2003. Geomorphologisch-bodenkundliche Untersuchungen an einer begrabenen Landoberfläche des Spätglazials auf dem Altdarss (Vorpommern). Diploma thesis, University of Greifswald, Dept. of Geography: $47 \mathrm{pp}$.

De Klerk, P., 2002. Changing vegetation patterns in the Endinger Bruch area (Vorpommern, NE Germany) during the Weichselian Lateglacial and Early Holocene. Review of Palaeobotany and Palynology 119: 275-309.

DIN V 4019-100, 1996. Baugrund. Setzungsberechnungen Teil 100: Berechnung nach dem Konzept mit Teilsicherheitsbeiwerten. Berlin.

Dücker, A. \& Maarleveld, G.C., 1957. Hoch- und spätglaziale äolische Sande in Nordwestdeutschland und in den Niederlanden. Geologisches Jahrbuch 73: 215-234. 
Ellenberg, H., 1992. Zeigerwerte von Pflanzen in Mitteleuropa (2nd edition). Goltze (Göttingen): 258 pp.

Faegri, K. \& Iversen, J., 1989. Textbook of pollenanalysis (4th edition). Wiley (Chichester): $328 \mathrm{pp}$.

Firbas, F., 1949. Spät- und nacheiszeitliche Waldgeschichte Mitteleuropas nördlich der Alpen. 1. Band: Allgemeine Waldgeschichte. Fischer (Jena): 480 pp.

Frahm, J.-P. \& Frey, W., 1992. Moosflora (3rd edition). Ulmer (Stuttgart): 528 pp. Friedrich, M., Knipping, M., van der Kroft, P., Renno, A., Schmidt, S., Ullich, 0. \& Vollbrecht, J., 2001. Ein Wald am Ende der letzten Eiszeit. Untersuchungen zur Besiedlungs-, Landschafts- und Vegetationsentwicklung an einem verlandeten See im Tagebau Reichwalde, Niederschlesischer Oberlausitzkreis. Arbeits- und Forschungsberichte zur sächsischen Bodendenkmalpflege 43: 21-94.

Fukarek, F., 1961. Die Vegetation des Darss und ihre Geschichte. Fischer (Jena): $321 \mathrm{pp}$.

Geologischer Dienst Schwerin, 1957. Geologische Karte 1:100.000, Blatt Stralsund-Bergen-Barth. Schwerin.

Görsdorf, J. \& Kaiser, K., 2001. Radiokohlenstoffdaten aus dem Spätpleistozän und Frühholozän von Mecklenburg-Vorpommern. Meyniana 53: 91-118.

Hijszeler, G.C.W.J., 1957. Late-glacial human cultures in the Netherlands. Geologie en Mijnbouw 19: 288-302.

Hilgers, A., 2006. The chronology and reconstruction of Late Glacial and Holocene dune development in the European sand belt - based on luminescence dating results from Germany and Poland. PhD thesis, University of Köln.

Hilgers, A., Murray, A.S., Schlaak N. \& Radtke, U., 2001. Comparison of Quartz OSL protocols using Late Glacial and Holocene dune sands from Brandenburg, Germany. Quaternary Science Reviews 20: 731-736.

Hoek, W.Z., 1997. Palaeogeography of Lateglacial vegetations. Aspects of Lateglacial and Early Holocene vegetation, abiotic landscape, and climate in the Netherlands. PhD thesis, Vrije Universiteit Amsterdam, Elinkwijk (Utrecht): $147 \mathrm{pp}$.

ISSS-ISRIC-FAO, 1998. World reference base for soil resources. FA0, World Soil Resources Report 84 (Rome): 91 pp.

Jacobson, G.L. \& Bradshaw, R.H., 1981. The selection of sites for palaeovegetational studies. Quaternary Research 16: 80-96.

Jankowski, M., 2002. Buried soils of the Torun Basin. In: Manikowska, B., Konecka-Betley, K. \& Bednarek, R. (eds): Paleopedology problems in Poland. Lodzkie Towarzystwo Naukowe (Lodz): 233-252.

Kaffke, A. \& Kaiser, K., 2002. Das Pollendiagramm 'Prerower Torfmoor' auf dem Darss (Mecklenburg-Vorpommern): neue Ergebnisse zur holozänen Biostratigraphie und Landschaftsgeschichte. Meyniana 54: 89-112.

Kaiser, K., 2001. Die spätpleistozäne bis frühholozäne Beckenentwicklung in Mecklenburg-Vorpommern - Untersuchungen zur Stratigraphie, Geomorphologie und Geoarchäologie. Greifswalder Geographische Arbeiten 24: 1-208.

Kaiser, K., 2004. Geomorphic characterization of the Pleistocene-Holocene transition in Northeast Germany. In: Terberger, T. \& Eriksen, B.V. (eds): Hunters in a changing world. Environment and archaeology of the Pleistocene-Holocene transition (ca. 11000 - 9000 B.C.) in Northern Central Europe. Leidorf (Rhaden/Westf.): 53-73.
Kaiser, K. \& Clausen, I., 2005. Palaeopedology and stratigraphy of the Late Palaeolithic Alt Duvenstedt site, Schleswig-Holstein (Northwest Germany). Archäologisches Korrespondenzblatt 35: 1-20.

Kaiser, K., Endtmann, E. \& Janke, W., 2000. Befunde zur Relief-, Vegetationsund Nutzungsgeschichte an Ackersöllen bei Barth, Lkr. Nordvorpommern. Bodendenkmalpflege in Mecklenburg-Vorpommern 47: 151-180.

Kasse, C., 1999. Late Pleniglacial and Late Glacial aeolian phases in the Netherlands. GeoArchaeoRhein 3: 61-82.

Kolstrup, E. \& Jørgensen, J.B., 1982. Older and Younger Coversand in southern Jutland (Denmark). Bulletin of the Geological Society of Denmark 30: 71-77.

Koster, E.A., 2005. Recent advances in luminescence dating of Late Pleistocene (cold-climate) aeolian sand and loess deposits in Western Europe. Permafrost and Periglacial Processes 16: 131-143.

Kowalkowski, A., Nowaczyk, B. \& Okuniewska-Nowaczyk, I., 1999. Chronosequence of biogenic deposits and fossil soils in the dune near Jasien, Western Poland. GeoArchaeoRhein 3: 107-125.

Krbetschek, M.R., Rieser, U., Zöller, L. \& Heinicke, J., 1994. Radioactive disequilibria in palaeodosimetric dating of sediments. Radiation Measurements 23: 485-489.

Kühn, P., 2003. Spätglaziale und holozäne Lessivégenese auf jungweichselzeitlichen Sedimenten Deutschlands. Greifswalder Geographische Arbeiten 28: $1-167$.

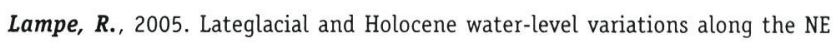
German Baltic Sea coast - review and new results. Quaternary International 133-134: 121-136.

Lampe, R. \& Janke, W., 2004. The Holocene sea level rise in the Southern Baltic as reflected in coastal peat sequences. Polish Geological Institute Special Papers 11: 19-30.

Lemke, W., 1998. Sedimentation und paläogeographische Entwicklung im westlichen 0stseeraum (Mecklenburger Bucht bis Arkonabecken) vom Ende der Weichselvereisung bis zur Litorinatransgression. Meereswissenschaftliche Berichte 31: 1-156.

Litt, T., Brauer, A., Goslar, T., Merkt, J., Balaga, K., Müller, H., RalskaJasiewiczowa, M., Stebich, M. \& Negendank, J.F.W., 2001. Correlation and synchronisation of Lateglacial continental sequences in northern central Europe based on annually laminated lacustrine sediments. Quaternary Science Reviews 20: 1233-1249.

Lorenz, S., 2006. Die spätpleistozäne und holozäne Gewässernetzentwicklung im Bereich der Pommerschen Haupteisrandlage Mecklenburgs. PhD thesis, University of Greifswald.

Ludwig, A.O., 2002. Die spätglaziale Entwicklung im östlichen Küstengebiet Mecklenburgs (Rostocker Heide, Fischland). Greifswalder Geographische Arbeiten 26: 83-86.

Manikowska, B., 1991. Vistulian and Holocene aeolian activity, pedostratigraphy and relief evolution in Central Poland. Zeitschrift für Geomorphologie N.F., Supplement 90: 131-141.

Mol, J., 1997. Fluvial response to Weichselian climate changes in the Niederlausitz (Germany). Journal of Quaternary Science 12: 43-60.

Murray, A.S. \& Wintle, A.G., 2000. Luminescence dating of quartz using an improved single-aliquot regenerative-dose protocol. Radiation Measurements 32: $57-73$. 
Oberdorfer, E., 1994. Pflanzenökologische Exkursionsflora (7th edition). Ulmer (Stuttgart): $1050 \mathrm{pp}$.

Pasda, C., 2002. Archäologie einer Düne im Baruther Urstromtal bei Groß Lieskow, Stadt Cottbus. Veröffentlichungen des Brandenburgischen Landesmuseums für Ur- und Frühgeschichte 33: 7-49.

Roeschmann, G., Ehlers, J., Meyer, B. \& Rohdenburg, H., 1982. Paläoböden in Niedersachsen, Bremen und Hamburg. Geologisches Jahrbuch F 14: 255-309.

Schirmer, W., 1999. Dune phases and soils in the European sand belt. GeoArchaeoRhein 3: 11-42.

Schlaak, N., 1998. Der Finowboden - Zeugnis einer begrabenen weichselspätglazialen oberfläche in den Dünengebieten Nordostbrandenburgs. Münchener Geographische Abhandlungen, Reihe A 49: 143-148.

Schlichting, E., Blume, H.-P. \& Stahr, K., 1995. Bodenkundliches Praktikum (2nd edition). Blackwell (Berlin, Wien): $295 \mathrm{pp}$.

Schweingruber, F.H., 1990. Anatomie europäischer Hölzer. Haupt (Bern, Stuttgart): $800 \mathrm{pp}$.

Spurk, M., Kromer, B. \& Peschke, P., 1999. Dendrochronologische, palynologische und Radiokarbon-Untersuchungen eines Waldes aus der Jüngeren Tundrenzeit. Quartär 49/50: 34-38.

Stapert, D. \& Veenstra, H.J., 1988. The section at Usselo; brief description, grain-size distributions, and some remarks on the archaeology. Palaeohistoria 30: 1-28.

Stoops, G., 2003. Guidelines for analysis and description of soil and regolith thin sections (Madison): $184 \mathrm{pp}$.

Stuiver, M. \& Reimer. P.J., 2005. Radiocarbon calibration program CALIB Rev 5.0 .1 (Washington).

Süß, H., 1968. Karpologische Fossilien aus dem Spätglazial der Rostocker Heide. Palaeontographica B 123: 237-242.

Terberger, T., de Klerk, P., Helbig, H., Kaiser, K. \& Kühn, P., 2004. Late Weichselian landscape development and human settlement in MecklenburgVorpommern (NE Germany). Eiszeitalter und Gegenwart 54: 138-175.

Tipping, R., Long, D., Carter, S., Davidson, D., Tyler, A. \& Boag, B., 1999. Testing the potential of soil-stratigraphic palynology in podsols. In: Pollard, A.M. (ed.): Geoarchaeology: exploration, environments, resources. Geological Society, Special Publications 165 (London): 79-90.

Turney, C.S.M., Coope, G.R., Harkness, D.D., Lowe, J.J. \& Walker, M.J.C., 2000. Implications for the dating of Wisconsinan (Weichselian) Late-Glacial events of systematic radiocarbon age differences between terrestrial plant macrofossils from a site in SW Ireland Quaternary Research 53: 114-121.

Van Geel, B., Coope., G.R. \& Van der Hammen, T., 1989. Palaeoecology and stratigraphy of the late glacial type section at Usselo (the Netherlands). Review of Palaeobotany and Palynology 60: 25-129.

Vandenberghe, D., Kasse, C., Hossain, S.M., De Corte, F., Van den Haute, P., Fuchs, M. \& Murray, A.S., 2004. Exploring the method of optical dating and comparison of optical and ${ }^{14} \mathrm{C}$ ages of Late Weichselian coversands in the southern Netherlands. Journal of Quaternary Science 19: 73-86.

Wohlfarth, B., Possnert, G., Skog, G. \& Holmquist, B., 1998. Pitfalls in the AMS radiocarbon-dating of terrestrial macrofossils. Journal of Quaternary Science 13: 137-145.

Zeeberg, J., 1998. The European sand belt in eastern Europe - and comparison of Late Glacial dune orientation with GCM simulation results. Boreas 27: 127-139. 